\title{
Der ,Krönungssturm“6 König Sigismund von Luxemburg, Großfürst Witold von Litauen und das gescheiterte politische Bündnis zwischen beiden Herrschern ${ }^{1}$
}

Zarys treści: Artykuł dotyczy sporów o planowaną koronację wielkiego księcia litewskiego Witolda (1429-1430). Zawiera analizę dokumentu koronacyjnego (krytyczną edycję w aneksie), instrukcji dla wysłanników króla rzymskiego na Litwę oraz identyfikację osób wchodzących w skład delegacji. Autor podkreśla znaczenie przewidzianej koronacji księcia Witolda jako podstawy do zawarcia sojuszu politycznego pomiędzy Litwą a krajami związanymi z królem Zygmuntem.

Content outline: The paper deals with the dispute around the planned coronation of the Lithuanian Grand Duke Vytautas (1429-1430). It contains an analysis of the coronation document (with its critical edition in the appendix), instructions for the envoys of the Roman King to Lithuania, and identification of members of the legation. The author stresses the importance of the expected coronation of Duke Vytautas as the foundation for a political alliance between Lithuania and the countries related to King Sigismund.

Słowa kluczowe: „burza koronacyjna”, Zygmunt Luksemburski, wielki książę litewski Witold, dyplomacja, Jagiellonowie

Keywords: „,coronation storm“, Sigismund of Luxembourg, Grand Duke of Lithuania Vytautas, diplomacy, Jagiellonian dynasty

\section{EINFÜHRUNG}

Die Kontroverse, welche die geplante Erhebung des Großfürsten Witold von Litauen zum König und damit auch seines Großfürstentums zum Königreich durch König Sigismund zwischen dem Erstgenannten und Władysław Jagiełło in den Jahren

${ }^{1}$ Die vorliegende Studie entstand im Rahmen des Projektes GA ČR 15-14758S - Zikmundova strana v husitských Čechách. Für hilfreiche Anregungen und Hinweise danke ich Sergeǐ Polehov vom Institut für russische Geschichte der Russischen Akademie der Wissenschaften (Institut Rossijskoj Istorii RAN) herzlich. Verzeichnis der in der Folge verwendeten Siglen: CEV - Codex epistolaris Vitoldi magni ducis Lithuaniae, hg. von A. Prochaska, Kraków 1882; CEXV - Codex epistolaris saeculi decimi quinti, Bd. II, hg. von A. Lewicki, Kraków 1891; RI XI - J. F. Böhmer, Regesta Imperii, XI. Regesten Kaiser Sigismunds (1410-1437) nach Archiven und Bibliotheken geordnet, hg. von K. Hruza, Bd. 2: Die Urkunden und Briefe aus den Archiven und Bibliotheken West-, Nord- und Ostböhmens, neubearb. von P. Elbel, S. Bárta, P. Bar, L. Reitinger, Wien-Köln-Weimar 2015. 
1429-1430 auslöste, hat unter anderem dank der fesselnden Erzählung eines der berühmtesten polnischen mittelalterlichen Geschichtsschreiber, Jan Długosz, einen prominenten Platz in der Historiographie eingenommen². Seitdem stieg die Zahl der diesem Thema gewidmeten Aufsätze und Monographien nicht nur in der polnischen und litauischen, sondern auch in der deutschsprachigen Historiographie dermaßen an, dass die jeweilige Fachliteratur heute kaum mehr überschaubar ist ${ }^{3}$. Trotzdem scheint es nützlich zu sein, die Wendepunkte und die Hauptthemen vor allem der jüngst publizierten Aufsätze kurz zu erörtern.

Seit dem 19. Jahrhundert wird der bis heute von polnischen Historikern meistens verwendete Begriff „Krönungssturm“ (pol. burza koronacyjna) gebraucht, um den dramatischen, ja brisanten Verlauf der jeweiligen Ereignisse hervorzuheben ${ }^{4}$. Auf ihre Interpretation in der polnischen Forschung hat die Darstellung in Długosz' Annales einen maßgeblichen Einfluss ausgeübt. Demzufolge wurde und wird die Frage einer litauischen Krone immer noch fast ausschließlich unter dem Blickwinkel des negativen Einflusses auf die polnisch-litauische Union behandelt. Erst Jarosław Nikodem ging einigermaßen von dieser Auffassung ab, indem er die einander gegenseitig ausschließenden dynastischen Interessen von Jagiełło und Witold als die wichtigste Ursache jenes Konflikts in den Vordergrund stellte. Wegen des gespannten Verhält-

2 Joannis Dlugossii Annales seu cronicae incliti regni Poloniae, lib. XI, Varsaviae 2000, S. 247-303. Eberhard Windecke erzählt über den Versuch, Witold zum König zu erheben, nur sehr knapp im Rahmen seines Berichts über dessen Tod, siehe Eberhart Windeckes Denkwürdigkeiten zur Geschichte des Zeitalters Kaiser Sigmunds, hg. von W. Altmann, Berlin 1893, S. 314: ,do starp herzog Witolt der groß fürste in der Littouwe, den er konig Sigemont zü eime konige gemacht haben wolt, als ein Romscher konig danne macht hett, und wolt im rich cleinöter darzü geben haben“. Einige merkwürdigen, aber nicht immer zuverlässigen Einzelheiten zur Gesandtschaft König Sigismunds nach Litauen sind in der Chronik des Lübecker Bürgers Hermann Korner zu finden (Die Chronica novella des Hermann Korner, hg. von J. Schwalm, Göttingen 1895, S. 503); zu dieser Passage siehe weiter С. В. П о л е х о в, Известие хроники Германа Корнера о Вилькомирской битве и его исторический контекст, in: Pabaisko mūšis ir jo epocha, Vilnius 2017, S. 91-133.

3 Eine ausführliche Übersicht der Literatur bietet G. B ł a s z c z y k, Burza koronacyjna. Dramatyczny fragment stosunków polsko-litewskich w XV wieku, Poznań 1998, S. 5-15; nochmals in: D e r s e 1 b e, Dzieje stosunków polsko-litewskich, Bd. II, Poznań 2007, S. 505582; vgl. dagegen J. N i k o d e m, Spory o koronację wielkiego księcia Litwy Witolda w latach 1429-1430, Tl. 1: „Burza koronacyjna” w relacji Jana Długosza, Lituano-Slavica Posnaniensia 6, 1994, S. 55-75, der hier (S. 55-58) die schlüssigen Aspekte einzelner historiographischer Darstellungen zutreffender erläutert. Zuletzt siehe R. P etra u s k a s, Korona Witolda: niedoszła koronacja i jej późniejsza legenda historyczna, in: Tradycja - metody przekazywania i formy upamiętnienia w państwie polsko-litewskim, XV - pierwsza połowa XIX wieku, Warszawa 2011, S. 13-23; J. N i k o d e m, Dlaczego jesienią 1430 r. Witold zrezygnował z planów koronacyjnych?, Lituano-Slavica Posnaniensia 14, 2012, S. 155-168; W. Z a w it k o w s k a, Walka polityczno-prawna o następstwo tronu po Władysławie Jagielle w latach 1424-1434, Rzeszów 2015. Im Kontext der Hussitenpolitik der beiden Herrscher (Władysław Jagiełło und Witold) behandelt den „Krönungssturm” auch J. Ni k o de m, Polska i Litwa wobec husyckich Czech w latach 1420-1433. Studium o polityce dynastycznej Władysława Jagiełły i Witolda Kiejstutowicza, Oświęcim ²2015, S. 392-404.

${ }^{4}$ Es wird angenommen, dass A. L e w i c k i, Powstanie Świdrygiełły. Ustęp z dziejów unii Litwy z Koroną, Kraków 1892, S. 34-50, als erster diese Bezeichnung verwendete. 
nisses zwischen beiden Vettern habe das Angebot der Krone für den Letzteren den bekannten diplomatischen Sturm ausgelöst ${ }^{5}$.

Der Weg Witolds zu einem der bedeutendsten Herrscher in der Geschichte Litauens und Osteuropas steht im Mittelpunkt des Buches von Giedre Mickūnaite் ${ }^{6}$. Die Krone und den Königstitel, die ihm nicht nur 1429-1430, sondern zwei- oder sogar dreimal angeboten wurden ${ }^{7}$, soll Witold für sein eigenes ,image-making“ und für die Unterstreichung seiner Souveränität ausgenutzt haben. In ihrer gut begründeten Argumentation weist die Autorin nach, dass es dem Großfürsten gelungen sei, auch bei seinen Gegnern in hohem Ansehen zu stehen ${ }^{8}$. In weiteren Studien wird an das Thema aus der Sicht König Sigismunds herangegangen, wobei nicht nur seine hinter einer vorsichtig taktierenden Politik verborgenen wirklichen Vorhaben ${ }^{9}$, sondern auch allgemein die Strukturen jenes Konflikts dargestellt werden, in den neben dem Deutschen Orden auch die Kurfürsten und der Papst verwickelt worden sind ${ }^{10}$.

${ }^{5}$ Nach J. N i k o d e m, Polska i Litwa, habe Witold eine von seinem Vetter Jagiełło grundsätzlich unabhängige Politik betrieben, sei es gegenüber dem Römischen König, dem Deutschen Orden oder dem hussitischen Böhmen. Der Großfürst habe mit dem polnischen König entweder nur gelegentlich und gegebenenfalls unter dem besonderen Druck der Umstände kooperiert, oder, wenn eine solche Zusammenarbeit ihm selbst einen gewissen politischen Gewinn einbringen konnte. Vgl. E. Male c zyńs ka, Społeczeństwo polskie pierwszej połowy XV wieku wobec zagadnień zachodnich. Studia nad dynastyczną polityką Jagiellonów, Wrocław 1947, die von der (fraglichen) Existenz einer kurialen bzw. luxemburgischen Partei in Polen überzeugt ist und die Politik Jagiełłos (nicht unumstrittener Weise) vornehmlich als Expansion nach Westen betrachtet, wodurch die Gestalt des Großfürsten zu stark in den Hintergrund gedrängt wird. Die jüngste Biographie von J. N i k o d e m, Witold wielki książę litewski (1354 lub 1355 - 27 października 1430), Kraków 2013, S. 381-422, fokussiert zwar ausschließlich auf die politische Tätigkeit des Großfürsten unter Marginalisierung sonstiger Aspekte, trotzdem scheint diese m. E. den vorhandenen Quellenangaben besser als die älteren Darstellungen zu entsprechen, vgl. z. B.: J. K. K o c h a n o w s k i, Witold wielki książę litewski. Studium historyczne, Lwów 1900; A. P r o c h a s k a, Ostatnie lata Witolda. Studium z dziejów intrygi dyplomatycznej, Warszawa 1882; А. Б а р б а ш е в, Витовтъ и его политика до Грюнвальденской битвы (1410 г.)., Санкт Петербургъ 1885; D e r s e l b e, Витовтъ. Последния двадцать леть княжения 1410-1430, Санкт Петербург 1891; J. P fitzner, Groszfürst Witold von Litauen als Staatsmann, Brünn-Prag-Leipzig-Wien 1930; H. Ło w mi á s k i, Witold wielki książę litewski, Lituano-Slavica Posnaniensia 7, 1997, S. 19-71 (Publikation eines Aufsatzes aus dem Jahr 1930).

${ }^{6}$ G. Mi c k ū na i te, Making a Great Ruler: Grand Duke Vytautas of Lithuania, Budapest - New York 2006.

7 Siehe Anm. 19.

${ }^{8}$ G. M i ck ū n a it è, Making, S. 64-75.

9 J. K. H o e n s ch, König/Kaiser Sigismund, der Deutsche Orden und Polen-Litauen. Stationen einer problembeladenen Beziehung, Zeitschrift für Ostmitteleuropa-Forschung 46, 1997, S. 1-44, bes. 33-37; D e r s e 1 b e, Kaiser Sigismund. Herrscher an der Schwelle zur Neuzeit 1368-1437, Darmstadt 1996, S. 347-351. Z. H. N ow a k, Kaiser Siegmund und die polnische Monarchie, Zeitschrift für historische Forschung 15, 1988, S. 423-436, stellt das komplizierte Verhältnis Sigismunds zu Polen in seiner europäischen Dimension dar, dagegen rückt J. G o 11, König Sigmund und Polen, Mitteilungen des Instituts für Österreichische Geschichtsforschung 15, 1894, S. 441-478; 16, 1895, S. 222-275, die Frage des Hussitentums in den Vordergrund.

${ }^{10}$ J. D ü c k e r, Sigismund und der Konflikt um die Königskrönung Witolds von Litauen (1429/30), in: Emperor Sigismund and the Orthodox World, Wien 2010, S. 17-25. 
Eine grundlegende Wende brachte am Ende des 19. Jahrhunderts die Edition von Antoni Prochaska in die Forschung, der viel bis dahin unbekanntes diplomatisches Material größtenteils aus dem damals in Königsberg aufbewahrten Ordensarchiv veröffentlichte und selbst in zahlreichen analytischen Aufsätzen und Monographien auswertete $^{11}$. Seither sind HistorikerInnen nicht mehr ausschließlich auf die, wenn auch meisterliche und zuverlässige, Narration von Jan Długosz angewiesen. Außer den durch Prochaska und andere Forscher erschlossenen Quellen, die unser Wissen über das Thema grundlegend vertieft haben, geben auch die Gutachten (consilia) der Krakauer und Wiener Juristen immer neue Anregungen für die aktuelle Forschungsdebatte $^{12}$. Dies bedeutet allerdings nicht, dass den Annales überhaupt keine Beachtung mehr zu schenken wäre, denn in ihnen werden die Hauptereignisse und die Gegenstände des Konflikts - trotz der Parteinahme des Geschichtsschreibers für die polnische Raison d'être - recht sachlich und glaubwürdig dargestellt, wie Jarosław Nikodem durch seine Analyse einschlägiger Passagen überzeugend darstellen konnte ${ }^{13}$.

Nach der Auffassung der polnischen Geschichte von Długosz, die in gewissem Maße von Bischof Zbigniew Oleśnicki von Krakau und seiner Umgebung geprägt wurde $^{14}$, soll die königliche Krönung Witolds das unvermeidliche Ende der polnischlitauischen Union bedeutet haben. Obwohl man auch heute dieser Ansicht zustimmen kann, werden diejenigen positiven oder negativen Beurteilungen, welche in der einschlägigen polnischen oder litauischen Historiographie immer noch zu finden sind,

${ }^{11}$ CEV. Das gesammelte Material wird am besten von A. Proch as ka, Ostatnie lata Witolda, ausgewertet. G. B ł a s z c z y k, Burza, S. 7-8, wies allerdings darauf hin, dass viele Dokumente in der angeführten Edition falsch datiert sind. Eine andere nützliche Edition zum Thema ist der CEXV.

12 Aus den Krakauer und Münchener Handschriften hat diese Quellen S. Z a c h o r o w s k i, Consilia w sprawie koronacji Witolda (1429-1430), in: Derselbe, Studia z historii prawa kościelnego i polskiego, Kraków 1917, S. 151-201, abgedruckt und erläutert.

${ }_{13}$ Neben dem in Anm. 3 zitierten Aufsatz siehe auch J. Ni k o de m, Spory o koronację wielkiego księcia Litwy Witolda w latach 1429-1430, Tl. 2: Próba rekonstrukcji wydarzeń, Lituano-Slavica Posnaniensia 7, 1997, S. 155-171; vgl. Rozbiór krytyczny Annalium Poloniae Jana Długosza z lat 1385-1444, hg. von J. Dąbrowski, Bd. I, Wrocław 1961, S. 236-249.

${ }^{14}$ Eine modernen Anforderungen genügende Biographie der führenden Gestalt der polnischen Politik im 15. Jahrhundert bleibt bis heute ein Desideratum. Als Ersatz lassen sich aber wenigstens ein Tagungsband: Zbigniew Oleśnicki. Książę kościoła i mąż stanu, hg. von F. Kiryk, Z. Noga, Kraków 2006, und eine Monographie über das bischöfliche Kanzleiwesen und die Verwaltung der Krakauer Diözese heranziehen: M. K o c zers k a, Zbigniew Oleśnicki i kościół krakowski w czasach jego pontyfikatu (1423-1455), Warszawa 2004. In einer beachtenswerten Studie, die als Prolegomena zu einer Biographie des Bischofs bezeichnet werden kann, hat J. N i k o d e m, Zbigniew Oleśnicki w historiografii polskiej, Kraków 2001, S. 15-57, gezeigt, dass der in der Historiographie hervorgehobene Einfluss des Bischofs auf das Geschichtsbewusstsein von Jan Długosz nicht selten unbegründet überschätzt wird. Seine angebliche Schlüsselrolle im „Krönungssturm“ wird dennoch in der polnischen Mediävistik weiterhin stark betont, siehe T. Graff, Działalność polityczna Zbigniewa Oleśnickiego i polskiej hierarchii kościelnej w dobie burzy koronacyjnej, Folia Historica Cracoviensia 14, 2008, S. 75-85, der jedoch nichts Neues in die Diskussion einbringt. 
dem Gegenstand nur teilweise gerecht, weil sie durch die jeweils zeitgebundenen nationalen Diskurse stark beeinflusst sind ${ }^{15}$.

Obwohl das Forschungsthema schon eine jahrhundertelange Tradition hat, wird immer noch manchen schriftlichen Dokumenten (wie z. B. der Krönungsurkunde oder den Instruktionen für die königliche Gesandtschaft) wie auch anderen materiellen Quellen und Objekten zu wenig Beachtung geschenkt (wie z. B. den Kronen, Geschenken usw.), die gerade für den Großfürsten Witold und seine Gemahlin vorgesehen waren oder sonst im Zusammenhang mit der geplanten Krönung entstanden. Diese Unterlassung führt unter anderem zur einseitigen Behauptung, König Sigismund habe den Krönungsplan ausschließlich darum vorbereitet, um den polnischen Herrscher Władysław Jagiełło von den Verhandlungen mit den Hussiten durch den von ihm selbst geschürten Streit zwischen beiden Vettern abzubringen. Es ist nicht zu leugnen, dass Sigismund die polnischen Aktivitäten in dieser Angelegenheit mit Zorn verfolgte und geradezu als Beleidigung seiner Person empfand, zumal Papst Martin V. den polnischen König sowie den Großfürsten von Litauen bevollmächtigt hatte, die Hussiten zur Rückkehr in den Schoß der Kirche zu bringen ${ }^{16}$. Trotzdem deuten einige bislang in der Forschung vernachlässigte Quellen darauf hin, dass Sigismund gleichzeitig weitere nachhaltige politische Projekte realisieren wollte, die aber wegen der letztendlich nicht vollzogenen Krönung gescheitert sind ${ }^{17}$.

\section{DIE GRUNDZÜGE DES „KRÖNUNGSSTURMS““}

Das Angebot der königlichen Krone für Witold wurde von Sigismund während der Tagung der drei Herrscher ${ }^{18}$ in Luck in Wolhynien (in heutigen Begriffen etwa die Nordwestukraine) im Januar 1429 bekannt gemacht, was für Jagiełło und seine Gefolgschaft zweifellos eine unangenehme Überraschung gewesen sein muss ${ }^{19}$.

${ }^{15}$ Zwei Sammelbände litauischer Historiker sind wegen der fehlenden fremdsprachlichen Zusammenfassungen für diejenigen, die die litauische Sprache nicht beherrschen, unerreichbar: Vytautas Didysis ir Lietuva, Vilnius 1996; Vytautas Didysis, hg. von P. Sležas, Kaunas 1930, Vilnius ${ }^{2} 1988$. J. P fi t z n e r, Groszfürst Witold, S. 178-209, interpretierte die Krönungsfrage nicht nur als Ausdruck des Strebens des litauischen Volkes nach Unabhängigkeit, sondern darüber hinaus als Niederschlag von dessen Willen, zum abendländischen Kulturkreis zu gehören.

${ }^{16}$ Die päpstlichen Vollmachtbriefe aus den Jahren 1428 und 1429 sind nur von Jan Długosz überliefert (Joannis Dlugossii Annales, lib. XI, S. 258-260, 262-263), siehe A. N a l e w a j e k, Dokument w Rocznikach Jana Długosza, Lublin 2006, S. 224; vgl. ferner J. N i k o de m, Polska i Litwa, S. 389-392; D e r s e 1 b e, Witold, S. 381-387.

17 Der Misserfolg bedeutete jedoch nicht, dass Sigismund seine politischen Pläne aufgab. Nach dem Tod Witolds im Oktober 1430 erneuerte er nämlich sein Angebot der königlichen Krone und damit auch des politischen Bündnisses für einen anderen litauischen Fürsten, Swidrigal (lit. Švitrigaila, pol. Świdrygiełło), siehe Regesta historico-diplomatica Ordinis Sanctae Mariae Theutonicorum 1198-1525, bearb. von E. Joachim, hg. von W. Hubatsch, pars I, vol. 1, Göttingen 1948, Nr. 5542-5543; weiters siehe A. L e w i c k i, Powstanie Świdrygiełły.

18 Der Römische sowie polnische König und der litauische Großfürst.

19 Alle Darstellungen des Tagungsablaufs beruhen mehr oder weniger auf Długosz (Joannis Dlugossii Annales, lib. XI, S. 247-257). Zur Tagung siehe aus der älteren Literatur: A. P r o c h a s k a, Ostatnie lata, S. 133-158; vgl. J. N i k o d e m, Spory, Tl. 1-2; D e r s e 1 b e, Witold, S. 387-389. Sigismund bot die Krone dem Großfürsten Witold schon 1410 an, um diesen dadurch von dessen Krieg gegen den Deutschen Orden abzubringen. Damals lehnte aber Witold 
Es ist kaum anzunehmen, dass das Vorhaben, Witold zum König und dessen Fürstentum zum Königtum zu erheben, mit ihm nicht im Voraus besprochen worden wäre. Das Angebot wurde jedenfalls für die polnische Gesandtschaft und den König Jagiełło zum Anlass, die Tagung vorzeitig zu verlassen. Während der folgenden Monate findet sich in der Korrespondenz zwischen Jagiełło, Witold und Sigismund besonders folgende Streitfrage wieder: welche Stellung hatten beide Herrscher zum Angebot des Römischen Königs während der Tagung bezogen? Offiziell konnten sie sich offenbar nicht mit einem eindeutigen „Ja“, bzw. „Nein“ dazu äußern. Witold beschuldigte seinen Vetter, dass dieser seine ursprüngliche Zustimmung widerrufen und dadurch Witolds Ehre beleidigt habe. Dem widersprach Jagiełło mit der Erklärung, dass er keine eindeutig zustimmende Aussage gemacht habe, weil in dieser Sache erst die Ansicht seines königlichen Rats hören wollte. Das Misstrauen zwischen beiden Vettern, das schon vor Jahrzehnten gesät worden war, erreichte nun seinen Höhepunk $\mathrm{t}^{20}$. Alle Beteiligten waren sich dessen bewusst, dass die königliche Krone für Witold ein sicheres Mittel darstellte, um die ersehnte und jahrelang erstrebte Unabhängigkeit von Jagiełło zu erreichen. Deshalb war es völlig ausgeschlossen, dass der polnische König oder der polnische Adel und besonders der Bischof von Krakau damit einverstanden gewesen wären ${ }^{21}$.

Sigismund darf zu Recht mit dem Ergebnis der Tagung in Łuck zufrieden gewesen sein, weil er dadurch seinen Zweck, wenn auch nur teilweise, tatsächlich erreichte. Während er selbst die Verhandlungen mit der hussitischen Gesandtschaft in Pressburg

das Offert ab, weil es nicht in seinem Interesse lag. Daran erinnert Witold in seinem Brief von 1430 an die polnischen Prälaten und Adeligen - CEV Nr. 1358 (hier falsche Datierung zum Juni 1429; vgl. G. B ł a s z c z y k, Burza, S. 124-125): Credimus vobis constare, quod magnus amicus corone sue regni Polonie semper fuimus, nec umquam quod esset contra honorem aut utilitatem eorundem [ali]quid facere attemptavimus, aut quidquam sine ipsorum consilio facere consveveramus, neque ecciam [sic!] coronari umquam cogitavimus, prout non ignoratis, quomodo in Kesmarkt, dum dominus Romanorum rex de coronacione nostri nobis sermonem movisset, nullo modo ad id voluimus consentire. Vgl. G. M i c k ū n a i tè, Making, S. 66, Anm. 317; weiter siehe Eberhart Windeckes Denkwürdigkeiten, S. 14-17, wo die Geschenke von Witold und dessen Gattin für Sigismund und dessen Gattin erstaunlicherweise sehr detailliert aufgezählt werden. Aus dem Jahr 1398 stammt auch die Nachricht, dass Jagiełło und Witold den Papst um die Krone für Litauen und russische Länder (Ruscheland) gebeten hätten (Codex diplomaticus Prussicus, hg. von J. Voigt, Bd. VI, Königsberg 1861, Nr. 61). Näheres zu diesem Vorstoß ist leider nicht überliefert, vgl. G. M i c k ū n a i tè, Making a Great Ruler, S. 65-66.

${ }^{20}$ Das Misstrauen spiegelt sich in einem Brief vom 15. Juni 1430 wider (nur als Abschrift überliefert), in dem der polnische König sich darüber beklagt, dass Witold mit ihm nicht kommuniziere, und deswegen diesen ermahnt, Bescheid über die bei ihm verweilenden Gesandtschaften zu geben (CEV Nr. 1356; hier falsche Datierung zum 26. Mai 1429; vgl. G. B $\nmid$ a s z c z y k, Burza, S. 126-127): admiramur super eo nec mirari possumus, in quo apud V. F. inculpamur; primo quandocunque cum aliquo convencionem habuistis, tunc nobis semper de ea intimastis, nunc vero dominus magister Prussie vobiscumque convencionem celebravit et de eo nobis nichil intimastis - - Insuper frater carissime, intimaverunt nobis Hussite, quod ad nos suos nunccios volunt destinare. Ideo dum venerint ad nos, quidcumque ab ipsis audiverimus, hoc ipsum vestre fraternitati volumus non latere. Et eciam frater carissime de Hungaria ad V. F. nuncii vadunt, ideo petimus, quid ab eis audieritis, nobis ea velitis intimare.

${ }_{21}$ Die Korrespondenz aus der ersten Hälfte des Jahres 1429 siehe beispielweise in CEV Nr. 1341, 1342, 1344, 1345, 1349, 1352. 
im Frühling und Herbst 1429 führte ${ }^{22}$, vermochte der polnische König weder militärische noch diplomatische Maßnahmen gegen die Hussiten zu ergreifen. Die Hussitenfrage wurde in der damaligen Korrespondenz immer häufiger als gegenseitige Anschuldigung thematisiert, dass die jeweilige Gegenpartei entweder Verhandlungen mit den Ketzern führe oder diese gegen ein anderes christliches Königreich aufhetze bzw. mit ihnen trotz des von Sigismund erlassenen Verbots Handel treibe ${ }^{23}$.

Das endgültige Ziel stellte jedoch zunächst die Krönung des Großfürsten und dessen Gemahlin dar, dann die Erhebung Litauens zum Königtum und schließlich der Abschluss des Bündnisses zwischen Sigismund als Römischem König und Witold als dem neugekrönten König von Litauen. Dazu brauchte Sigismund jedoch eine eindeutige und definitive Entscheidung des Großfürsten, der dem Vorschlag Sigismunds in Łuck nur unverbindlich zustimmte, weil Witold aus taktischen Gründen den Anschein wahrte, als ob er tatsächlich die Meinung Jagiełłos einholen hätte wollen. Noch im Februar war der Römische König nicht sicher, für welche Möglichkeit sich Witold schließlich entschieden hatte ${ }^{24}$. Die kompromisslose Stellungnahme der Polen und Jagiełłos, dessen Gesandtschaften zum Römischen König ${ }^{25}$, zum Papst ${ }^{26}$ und zu

${ }^{22}$ Dazu siehe D. C o u fa l, Polemika o kalich mezi teologií a politikou 1414-1431. Předpoklady basilejské disputace o prvním z pražských artikulů, Praha 2012, S. 211-246.

${ }^{23}$ Siehe CEV Nr. 1349, 1350, 1352, 1353, 1357, 1365. Die königlichen Mandate rund um das Handelsverbot analysiert A. K a a r, Neue Mittel der Kriegsführung? König/Kaiser Sigismund und das Handelsverbot gegen die Hussiten in Böhmen, in: Heilige, Helden, Wüteriche. Herrschaftsstile der Luxemburger (1308-1437), Köln-Weimar-Wien 2017, S. 223-242.

${ }^{24}$ Siehe den Brief vom 18. Februar 1429 (CEV Nr. 1346), in dem Sigismund den Hochmeister Paul von Rusdorf um Nachricht ersuchte, ,ab unsir bruder herczog Wytowd di cronunge ufnemen werde ader nicht".

${ }_{25}$ Siehe den Brief vom Jahresende 1429 (CEV Nr. 1341; vgl. G. B ł a s z c z y k, Burza, S. 60-66), in dem Jagiełło dem Römischen König erklärt, warum er seine Zustimmung zur Krönung des Großfürsten nicht geben könne. Seine Begründung lässt sich in drei Punkten wiedergeben: 1. Die Krönung könne Zwietracht zwischen Polen und Litauen säen; 2. Nach dem Tod Witolds dürften die litauischen Adeligen ihren König eigenständig ohne Teilnahme der Polen wählen (was aber das polnisch-litauische Bündnisdokument von Horodlo aus 1413 untersagt, siehe Anm. 102) und 3. Würde die Krönung vollzogen, würde dies die dauernde Entfremdung des dem Großfürsten nur auf Lebenszeit zugewiesenen Herrschaftsgebietes vom Königreich Polen bedeuten.

${ }_{26}$ Schon in der Mitte des Jahres 1429 mahnte Papst Martin V. beide Vettern, Einigkeit zu bewahren und gemeinsam gegen die böhmischen Ketzer vorzugehen, ohne den Krönungsplan überhaupt zu erwähnen (CEXV II, Nr. 173; vgl. G. B ł a s z c z y k, Burza, S. 99-101). Wahrscheinlich schloss der Papst die Krönung damals noch nicht aus, falls er als Schiedsrichter durch seinen Legaten den Streit schlichten hätte können (dies ergibt sich aus dem Bericht des päpstlichen Legaten, des Dominikaners Andreas von Konstantinopel - CEV Nr. 1370, welchen aber J. G o 11, König Siegmund. Tl. 2, S. 254-255, Anm. 5, und nach ihm G. B ł a s z c z y k, Burza, S. 143, ins Jahr 1430 setzen). Die päpstliche Initiative gefiel dem Römischen König gar nicht, zumal im päpstlichen Schreiben Sigismund als der eigentliche Stifter der Zwietracht bezeichnet wird (CEV Nr. 1393; Reg.: RI XI, Nr. 7579). Der polnische König entsandte dann seine Gesandtschaft nach Rom mit den Gutachten (consilia) der Krakauer Universität, die die Befugnis des Römischen Königs zur Verleihung königlicher Kronen anzweifelten (siehe Anm. 12, wie auch G. B ł a s z c z y k, Burza, S. 101-103). Nicht allein, aber auch aufgrund dieser Gutachten entschloss sich der Papst, die polnische Stellungnahme vollkommen zu unterstüt- 
den Kurfürsten ${ }^{27}$ entsandt wurden, um die Krönung in Litauen zu verhindern, trug dann zur eindeutigen Entscheidung des Großfürsten bei. Im Sommer 1429 bestellten dessen Boten dem polnischen König, dass Witold die Krone von Sigismund ohne Rücksicht auf die Meinung Jagiełłos empfange ${ }^{28}$.

Um die Entscheidung des Großfürsten zu festigen, ordnete Sigismund einige Gesandtschaften nach Litauen ab. Im Mai und Juni 1429 überbrachten Herbort von Fulstein, der außerordentliche Gesandte des Römischen Königs ${ }^{29}$, und Małdrzyk, der Sekretär des Großfürsten ${ }^{30}$, Witold nicht nur die Abkommensentwürfe Sigismunds, sondern auch dessen Antwort auf die hussitischen Forderungen ${ }^{31}$. Im Hinblick auf

zen, siehe J. D r a b i n a, Papiestwo - Polska w latach 1384-1434, Kraków 2003, S. 91-96; J. D ü c k e r, Sigismund, S. 23-24.

27 Dies geschah erst später, als die Krönungsfrage auf dem Hoftag in Pressburg am Ende des Jahres 1429 behandelt wurde (RTA IX, Nr. 286). Die Sache wurde aber noch danach und zwar auf dem nächsten Hoftag in Nürnberg im Frühling 1430 eingehend behandelt, wo die polnische Gesandtschaft sowie ein Bote von Witold erschienen; siehe die in der Reichsversammlung vorgetragene polnische Deklaration in CEXV II, Nr. 179; vgl. Deutsche Reichtagakten, Bd. IX, Gotha 1887, Nr. 331, 336. Aber schon Ende Dezember versicherten einige Kurfürsten dem litauischen Großfürsten, dass sie gar nicht beabsichtigten, den Römischen König abzusetzen (RTA IX, Nr. 284); vgl. weiter G. B ł a s z c z y k, Burza, S. 104-105, 117-119; J. D ü c k e r, Sigismund, S. 20-23. Die kaum durchsetzbaren Absetzungspläne der Kurfürsten, die mit der könglichen Politik gegenüber den Hussiten unzufrieden waren, wurden von Sigismund trotzdem ernst genommen (Ch. M a th i e s, Kurfürstenbund und Königtum in der Zeit der Hussitenkriege. Die kurfürstliche Reichspolitik gegen Sigmund im Kraftzentrum Mittelrhein, Mainz 1978, S. 250-251). Zu den Versammlungen bzw. Hoftagen in Pressburg und Nürnberg 1429-1430 siehe S. W e fe r s, Das politische System Kaiser Sigmunds, Stuttgart 1989, S. 164-166, 168; G. A n n a s, Hoftag - Gemeiner Tag - Reichstag. Studien zur strukturellen Entwicklung deutscher Reichsversammlungen des späten Mittelalters (1349-1471), Bd. II, Göttingen 2004, S. 287-298.

${ }^{28}$ Nach einem Bericht vom 23. Juli 1429 (CEV Nr. 1362) sollen die litauischen Gesandten dem polnischen König gesagt haben, dass dominus noster magnus dux Serenitati Vestre [Jagiełł] mandavit referre, quod sive placeat sive eciam displaceat Vestre Serenitati, ipse [Witold] vult coronam recipere et habere.

${ }^{29}$ P. E 1 b e 1, „Scio, quod vos Moravi estis timidi et michi non fideles“. Moravané ve strukturách dvora Zikmunda Lucemburského, Mediaevalia historica Bohemica 12, 2009, Nr. 2, S. 88-89.

${ }^{30} \mathrm{Zu}$ ihm siehe M. K o s m a n, Małdrzyk Mikołaj, in: Polski słownik biograficzny, Bd. XIX (1974), S. 428-429; S. S z y b k ow s k i, Polish Staff as a Social Group in the Chancery of Grand Duke Witold, Quaestiones Medii Aevi Novae 3, 1998, S. 75-94; A. S z y m c z a k ow a, „Nobiles Siradienses”. Rody Porajów, Pomianów, Gryfów, Kopaczów i Pobogów, Warszawa 2011, S. 29-37.

${ }^{31}$ Der Brief von Witold an Jagiełło (CEV Nr. 1357): Sed recogitantes, quod Maldrzik secretarius noster et Herbord domini regis Romanorum nunccius sunt in propinquo - Nunc autem venerunt predicti Maldrzik et Herbord [von Fulstein], qui nobis non alia nisi que pacis sunt dileccionis et amicicie tam pro Serenitate Vestra, quam pro nobis ab ipso domino Romanorum rege retulerunt - -. Item predicti Herborth et Maldrzik attulerunt nobis copiam quandam lingwagii bohemici oblacionis facte per dominum regem Romanorum Hussitis Bohemis, nunc in Bohemia pro finali responso sibi dando convencionem generalem celebrantibus, quam vobis dirigimus, ex qua sencietis non talia uti dicebantur de domino rege Romanorum per ipsum ab eisdem Hussitis postulari, et quod cum eisdem adhuc ad nichilum finale sit deventus bene patet. 
den erwarteten Krönungsakt war jedoch noch wichtiger, dass Witold etwas später (im Zusammenhang mit einer anderen Gesandtschaft) manche königlichen Geschenke von Sigismund und dessen Gemahlin Barbara erhielt: die Insignien (Bilddevisen) des Drachenordens $^{32}$, einen mit Smaragden geschmückten Fingerring ${ }^{33}$ und ein seidenes Zelt $^{34}$. Die zwei erstgenannten Geschenke empfing Witold schon im Sommer 1429; das Zelt wurde hingegen wahrscheinlich erst gemeinsam mit den Kronen ein Jahr später abgeschickt ${ }^{35}$. Laut Sigismund waren die Kronen und andere Gegenstände zwar schon im Juli 1429 vorbereitet gewesen ${ }^{36}$, doch ihre Absendung verzögerte sich aus nicht näher bekannten Gründen um ein Jahr. Diese Verspätung hatte schwerwiegende Folgen, da die Kronen samt anderen wichtigen Gegenständen den Adressaten letztendlich nicht erreicht haben (siehe unten).

Sensu stricto können zwar unter den geschenkten Gegenständen nur die Kronen als eigentliche Herrschaftszeichen betrachtet werden, doch bedeutet das nicht, dass für den Großfürsten von Litauen die übrigen Gegenstände von geringer Bedeutung

${ }^{32}$ Die Übergabe der Insignien bezeugen die Originalurkunde Sigismunds vom 3. August 1429 mit dem Majestätssiegel in: Wien, Haus-, Hof- und Staatsarchiv, Bestand Allgemeine Urkundenreihe, sub dato (Ed.: Codex diplomaticus Hungariae ecclesiasticus ac civilis, Bd. X/8, hg. von G. Fejér, Budae 1843, Nr. 291; Reg.: RI XI, Nr. 7352, Nr. 7444a; RI XI/2 Neub. Nr. 76) sowie die Erzählung davon in der Chronik von Jan Długosz (Joannis Dlugossii Annales, lib. XI, S. 269-271). Zum Drachenorden siehe P. L ö v e i, Hoforden im Mittelalter, unter besonderer Berücksichtigung des Drachenordens, in: Sigismundus Rex et Imperator. Kunst und Kultur zur Zeit Sigismunds von Luxemburg (1387-1437). Ausstellungskatalog, Mainz 2006, S. 251-263, hier S. 261, der behauptet, dass das Ordenszeichen auch dem polnischen König Władysław Jagiełło verliehen worden sei; siehe weiters I. G r a u s, Dračí rád Žigmunda Luxemburského a jeho symbolika, Slovenská archivistika 31, 1996, Nr. 2, S. 86-106; D e r s e 1 b e, Rád Draka a jeho insignie, Vojenská história 10, 2006, Nr. 4, S. 3-25; M. S. P o p o v i ć, The Order of the Dragon and the Serbian Despot Stefan Lazarević, in: Emperor Sigismund and the Orthodox World, Wien 2010, S. 103-106.

${ }_{33}$ Siehe den Brief der Königin Barbara an den Großfürsten vom 26. August 1429 (CEV Nr. 1373): Mittimus Vestre Fraternitati annulum smaragdo fulcitum, quem ut nostri amore gestare velitis vos affectuosius deprecamur. Sie wolle dadurch auch ihre Dankbarkeit für die großzügige Gastfreundschaft Witolds in Łuck zeigen (gratissimo animo et debito honore facimus, nam nobis in domo vestra inmensos honores impendistis), siehe D. D v o řá k o vá, Čierná král'ovná Barbora Celjská (1392-1451). Životný príbeh uhorskej, rímsko-nemeckej a českej král'ovny, Budmerice-Bratislava 2013, S. 136.

${ }^{34}$ Das bezeugt die Liste von 1429-1430, die die damals auf der Pressburger Burg aufbewahrten königlichen Zelte verzeichnet (Budapest, Magyar Nemzeti Levéltár, Magyar Országos Levéltár, Sign. DL 25933: Anno 1429. Tentoria domini regis dimissa in castro Posoniensis wlgo cherge sunt XXXII --. Item de istis dominus rex recepit $V$ secum Wiennam, de quibus unum erat cum serico et propinat duci Witaldo. In der vorliegenden Literatur hat D. D v o řá k o vá, Čierná král'ovná, S. 136, als erste darauf hingewiesen und vermutet, Sigismund hätte das Zelt schon auf die Tagung in Łuck mitgebracht. Aus dem angeführten Verzeichnis geht aber eindeutig hervor, dass der Eintrag, welchen eine andere Schreiberhand nachgetragen hatte, erst nach dem Aufenthalt Sigismunds in Wien im Juli 1430 entstanden sein muss.

${ }^{35}$ Siehe Anm. 34.

${ }^{36}$ Siehe den Brief Sigismunds vom 27. Juli 1429 in CEV Nr. 1365: Nos enim coronas et singula apparamenta cum tali decore preparavimus pro V. F. et illustra conthorali vestra sorore nostra carissima, et vobis illas transmittemus in solempnitate tanta, prout [de]cet. Reg.: RI XI, Nr. 7347. 
waren $^{37}$. Der einem anderen Herrscher übersandte Fingerring konnte im allgemeinen Sinne im Mittelalter als Lehnszeichen angesehen werden, was jedoch hier der Intention des Römischen Königs nicht entsprach, da Sigismund den künftigen litauischen König und dessen Nachfolger laut der Krönungsurkunde als reges liberi nec nobis, nec sacro imperio, nec cuicunque alteri subditi seu vasalli betrachten wollte ${ }^{38}$. Wohl deswegen wurde der Ring nicht von Sigismund selbst, sondern von dessen Gemahlin Barbara übersandt, um jegliche Andeutung eines Lehnsverhältnises zum Großfürsten zu vermeiden ${ }^{39}$. Der Smaragdring, das Zelt aus Seide und vor allem die Drachenordensinsignien galten sicher als Ehrung für Witold und Ausdruck großer Wertschätzung, welcher Witold sich nicht nur beim Römischen König und dessen Gattin, sondern auch bei anderen abendländischen Herrschern erfreute.

In der Urkunde, durch welche Witold die Ordensinsignien verliehen werden, erklärt Sigismund die Motive zur Stiftung des Drachenordens im Jahr 1408. Primärer Anstoß dazu sollen die Feinde des christlichen Glaubens und die abgefallenen Christen gewesen sein, die angeblich die Königreiche Sigismunds gefährdeten. $\mathrm{Zu}$ deren Vernichtung bzw. Befriedung werden jetzt sowohl Witold als auch die anderen Ordensgenossen berufen ${ }^{40}$. Diese Idee wird im Ordenszeichen selbst veranschaulicht, das einen zu einem Kreis gekrümmten Drachen mit dem um dessen Hals gewundenen Schwanz darstellt. Über ihm steht das Kreuz, das auf Jesus Christus, den Erlöser, hindeutet, der nach seiner Auferstehung die Kammern der Hölle zerrissen und das Haupt des Leviathan und gewundenen Drachens durch das Mysterium desselben Kreuzes machtvoll zertreten habe. Die Beschreibung des Ordenszeichens in der Urkunde für Witold weicht etwas von jener in der älteren Gründungsurkunde $a b^{41}$. Grundsätzlich kamen zwei Typen vor - mit dem Kreuz über dem Rücken des Drachen und dem Drachen ohne Kreuz, wobei der erste Typ für die Ordensmitglieder ersten Ranges bestimmt war (d. h. etwa für den Großfürsten Witold) ${ }^{42}$. Unter den realiter überlieferten Ordenszeichen sei auf dasjenige mit dem flammenden Kreuz hingeweisen, das ursprünglich aus graviertem und vergoldeten Silber hergestellt wurde und vor 1903 zusammen mit circa sechs anderen Exemplaren in Livland (!) gefunden

37 P. E. S c h r a m m, Herrschaftszeichen: gestiftet, verschenkt, verkauft, verpfändet. Belege aus dem Mittelalter, Nachrichten der Akademie der Wissenschaften in Göttingen, Philosophisch-historische Klasse 5, 1957, S. 162-226, hier S. 186, erwähnt nur die erfolglose Übersendung der Kronen.

${ }^{38}$ Siehe Anhang; vgl. K. H a u c k, Halsring und Ahnenstab als herrscherliche Würdezeichen, in: Herrschaftszeichen und Staatssymbolik. Beiträge zu ihrer Geschichte vom dritten bis zum sechszehnten Jahrhundert von Percy Ernst Schramm mit Beiträgen verschiedener Verfasser, Bd. I, Stuttgart 1954 (Schriften MGH 13/1), S. 145-212, hier S. 190; P. E. S c h r a m m, Herrschaftszeichen, S. 214.

${ }^{39}$ Vgl. zur Übergabe eines Fingerringes durch Władysław Jagiełło an dessen Bruder, den litauischen Fürsten Swidrigal (С. В. По л е х в, Наследники Витовта. Династическая война в Великом княжестве Литовском в 30-е годы XV века, Москва 2015, S. 173-176, wo Überlegungen zur Bedeutung und Wahrnehmung dieses Aktes angestellt werden).

${ }^{40}$ Codex diplomaticus Hungariae, Bd. X/8, Nr. 291: tam hostes fidei Christiane, qui nobis et regnis nostris sunt e vicinio contermini, conterere, ac eciam malos christicolas possemus ad pacis pulchritudinem revocare.

${ }^{41}$ Codex diplomaticus Hungariae, Bd. X/4, Nr. 317.

${ }^{42}$ M. S. P op ovi ć, The Order, S. 104. 
worden sein soll. Man darf wohl vermuten, dass dieses Exemplar mit dem nur der Beschreibung nach bekannten Ordenszeichen für Witold identisch gestaltet war ${ }^{43}$.

Aus der Urkunde für Witold sind noch zwei für seine vorgesehene Erhebung wichtige Punkte hervorzuheben. Erstens: jeder Träger des Ordenszeichens vepflichtet sich, Witwen und Waisen der verstorbenen Mitglieder in ihren Besitztümern und Rechten vor jeglichen Übergriffen zu schützen und gegen Schmach und jegliche drohende Gefahr zu verteidigen. Zweitens: durch den Drachenorden seien Sigismund und Witold wahre Brüder und Genossen (veri fratres et socii consodales) geworden und sollen einander in allen Notwendigkeiten unermüdlich wechselseitig unterstützen. Durch diese neue Verbundenheit verpflichteten sich der Römische König und der Großfürst von Litauen, wenn sie dazu aufgerufen würden, Witwen und Waisen beiderseits vor jeglichen Unterdrückern zu beschützen (nullatenus deserere, sed fideliter defensare et ab impetitoribus preservare $)^{44}$. Die angeführten zwei Punkte bewegen sich in dieselbe Richtung. Das politische Bündnis mit dem Römischen König hatte für Witold vor dem Gesichtspunkt der durch ihn betriebenen dynastischen Politik grundlegende Bedeutung. Es gewährleistete nämlich den Schutz der Nachfolgeansprüche von dessen eventuellen Nachkommen gegen jegliche Einsprüche.

Witold musste sich aller daraus abzuleitenden Implikationen bewusst sein, die offenkundig gegen die Interessen des polnischen Königreichs und König Władysław Jagiełłos gerichtet waren, der sich selbst immer als Lithwanie princeps supremus titulieren ließ (dagegen verwendete Witold nur den Titel magnus dux Lythwanie) ${ }^{45}$. Deswegen musste der Großfürst beim offiziellen Empfang der Ordensinsignien, welche ein sonst unbekannter österreichischer Ritter namens Leonhard nach Litauen in Wołkowysk (heute im westlichen Teil Weißrusslands) gebracht hatte, in Anwesenheit der polnischen Gesandtschaft ${ }^{46}$ öffentlich erklären, er hätte diese nicht als Zeichen der Bündnisgenossenschaft mit dem Römischen König, sondern lediglich als Auszeichnung seiner Person und Würde entgegengenommen. Witold wollte stets den Anschein erwecken, er hätte sich gegenüber dem Königreich Polen und Jagiełł nie treubrüchig verhalten. Der Chronist Długosz schließt seine Erzählung über den Empfang der Ordensinsignien mit der Anspielung auf das Ordenszeichen (den gekrümmten und mit Blut befleckten Drachen) und einem biblischen Zitat, welches ein künftiges kriegerisches Blutvergießen unter den Christen prophezeien sollte ${ }^{47}$.

${ }^{43}$ Sigismundus Rex et Imperator (wie Anm. 32), S. 340, Nr. 4.40.

${ }^{44}$ Codex diplomaticus Hungariae, Bd. X/8, Nr. 291.

45 Vgl. CEXV II, Nr. 84.

${ }^{46}$ An der Spitze der Gesandtschaft, die dem Großfürsten die Krone des Königreichs von Polen antrug (sic!), standen der Bischof von Krakau, Zbigniew Oleśnicki, und der Wojewode von Krakau, Jan von Tarnów, siehe G. B ł a s z c z y k, Burza, S. 90-98.

47 Joannis Dlugossii Annales, lib. XI, S. 270-271: Nam et pro illo tempore, quo cum nunciis regis in Wilkowiska agebat, venit miles Austrie Leonardus ex parte Sigismundi Romanorum et Hungarie regis missus, ferens sibi insignia societatis sue certis legibus quas quilibet accipiens iuramento intemerate servaturum se stringebat, qualificatas, quibus cautum erat, ut unus alterum in adversis et prosperis et quocunque casu nunquam desereret. Draco autem societatis predicte erat insignie rotunda figura se volvens et capite caudam complectens faucibus apertis et flammam ructuantibus, cruore in spina dorsi in modum crucis consperus, cui signum crucis radios emittens erat suprapositum scripturam in medio talem continens: $O$ quam misericors 
Sigismund und Witold müssen fest entschlossen gewesen sein, die geplante Krönung zu vollziehen. Trotzdem kam es um die Wende des Jahres 1429/1430 zu einer Verzögerung, die vor allem durch die polnische Appellation bei der römischen Kurie und die Gesandtschaften zu den Reichsversammlungen ${ }^{48}$ verursacht wurde. Die Appellation wurde wiederum durch juristische Gutachten (consilia) der Gelehrten der Krakauer Universität gestützt ${ }^{49}$. Fünf Krakauer Juristen ${ }^{50}$ gaben ein negatives Urteil über die Frage, ob der Römische König, der zwar vom Papst bestätigt, aber noch nicht zum Kaiser gekrönt und geweiht sei, königliche Kronen verleihen und ein Königtum schaffen dürfe ${ }^{51}$. Sie erläuterten, dass das Recht auf die Kronenverleihung zwar auf der Kaiserwürde (dignitas) beruhe, doch erst im Anschluss an die vom Papst vollzogene Kaiserkrönung und -weihe in Anspruch genommen werden könne. Außerdem dürfe ein neues Königreich niemanden in seinen Rechten beinträchtigen. Das neugeschaffene litauische Königreich würde aber Litauen, ein untrennbares Element des Königreichs, von Polen entfremden und dadurch dessen Rechte beschädigen. Schließlich dürfe auch der Römische König als Laie keine königliche Salbung ohne päpstliche Bewilligung durchführen.

Sigismund konnte diese Argumente nicht ignorieren, zumal Papst Martin V. der polnischen Stellungnahme zuneigte und Witold, was noch gefährlicher war, ernste Bedenken gegen die Rechtmäßigkeit seiner eigenen Erhebung zum König äußerte ${ }^{52}$.

est Deus iustus et clemens. Insignia huiusmodi in presencia nunciorum regalium oblata, dux Withaudus pro vinculo societatis ineunde respondit se nullatenus pro fraternitatis et lige vinculo sed pro muneris officio, ne iuramentum Wladislo regi Polonie prestitum per prestacionem alterius videretur temerasse, suscepturum. Tali responso accepto nuncii in Poloniam reversi, que secum acta erant, singillatim Wladislao Polonie regi denunciant et exponunt. Ad illaqueandum siquidem animum Alexandri Withaudi ducis prefati draconis insigne mittebatur pro societate, ut Withaudus ipse amicus fieret Imperii et socius. Tunc prefato scriptura illa implebatur prophetalis: 'Draco ille, quem formasti ad illudendum ei' [Psalmi c. 103, v. 26], draco siquidem ille et tortuosus et sanguine respersus cum signo crucis formatus apparuit, significans per suum auctorem et illius suggestionem sanguinem Christianorum per bella fundi oportere. Eine englische Übersetzung und Interpretation dieser Passage bei J. J e ff e r s o n, The Holy Wars of King Wladislas and Sultan Murad. The Ottoman-Christian Conflict from 1438-1444, Leiden-Boston 2013, S. 132-133.

48 Die polnische Stellungnahme wurde auf der Reichsversammlung in Nürnberg im April 1430 vorgetragen (CEXV II, Nr. 179). Auf derselben Versammlung wurden auch die Interessen des Großfürsten durch seinen litauischen Gesandten vertreten. Der Inhalt seiner Mission ist aber nicht bekannt (RTA IX, Nr. 336).

49 Das Gutachten wurde von S. Z a c h or ow s k i, Consilia, S. 187-192, ediert; siehe weiters G. Bła s z c z y k, Burza, S. 101-103.

${ }^{50}$ Alle waren doctores decretorum: Stanisław von Skarbimierz, Jakub von Zaborów, Tomasz von Chrobrze, Adam von Będków und Jan Elgot. Über die Gelehrten im Dienste des Königreichs Polen unter der Regierung Władysław Jagiełłos siehe K. O ż ó g, Uczeni w monarchii Jadwigi Andegaweńskiej i Władysława Jagiełly (1384-1434), Kraków 2004.

${ }^{51} \mathrm{~S}$. Z a c hor ow sk i, Consilia, S. 187: Ad questionem, qua queritur, an in regem Romanorum electus canonice, cuius electio a papa est approbata, cum nondum sit imperator aut per ecclesiam iuxta ritum ab antiquo tentum in imperatorem consecratus, poterit denuo aliquem impetratorem in regem eligere et creare.

${ }^{52}$ Einerseits schrieb Witold dem Hochmeister, dass er die Krone jedenfalls auch gegen den Willen Polens empfangen werde (der Brief vom 15. März 1430 in CEV Nr. 1402), andererseits 
Daraufhin beauftragte Sigismund seinen italienischen Höfling und Juristen Baptista Cigala $^{53}$ sowie die Gelehrten der Wiener Universiä ${ }^{54}$, eigene juristische Gutachten zu verfassen, die die polnischen Einwände entkräften sollten ${ }^{55}$. In allen Gutachten wird einstimmig festgestellt, dass der Römische König, dessen Wahl vom Papst anerkannt sei, noch vor seiner Weihe zum Kaiser über die totalis potestatis imperialis plenitudo verfüge (d. h. auch jemanden zum König erheben könne) ${ }^{56}$. Im zweiten Gutachten Cigalas bzw. der Wiener Dekretisten wurden noch zwei weitere Fragen behandelt, die selbstverständlich negativ beantwortet wurden, nämlich, ob eine päpstliche Bewilligung und eine Weihe (consecracio) bzw. eine Salbung (unctio) zur königlichen Krönung erforderlich seien ${ }^{57}$. Allerdings konnten weder Cigala noch die Wiener Dekretisten bestreiten, dass die Weihe bzw. Salbung der kirchlichen Autorität zustehen ${ }^{58}$. Die Frage war nur, wer die Weihe zum König erteilen dürfe: der Papst, der Erzbischof oder ein einfacher Priester? Unter diesen drei Möglichkeiten neigten die Gelehrten zurückhaltend der zweiten Option zu. Sie wollten nämlich gewisse Sonderfälle, bei welchen sich der Papst den Anspruch vorbehalte ${ }^{59}$, nicht beurteilen. Jedoch stimmten sie schließlich mit gewissem Vorbehalt und Rücksicht mit den Prärogativen der römischen Kirche überein, dass der jeweilige Ortsbischof für die königliche Salbung und Weihe zuständig sei ${ }^{60}$.

Diese Gutachten sollten vor allem den Großfürsten überzeugen, der befürchtete, seine neue königliche Würde könnte wegen rechtlicher und zeremonieller Mängel zweifelhaft und anfechtbar sein. Witold wollte dies nicht zulassen und gab auch Sigismund darüber Bescheid. In seinem Brief vom Juli 1430 an Witold verwendete der Römische König die in den Gutachten festgelegte Argumentation und empfahl dem

wurde er von Sigismund ermahnt, seine eigene Entscheidung nicht zu ändern, siehe die Briefe vom 31. Dezember 1429 und vom Juli 1430 (CEV Nr. 1392, 1424).

53 Siehe zu ihm G. B e in h off, Die Italiener am Hof Kaiser Sigismunds (1410-1437), Frankfurt a. M. 1995, S. 160-162, die aber seine Reise nach Litauen nicht erwähnt.

${ }^{54}$ Alle waren doctores decretorum: Johann Gwerlich, Kaspar Meiselstein, Konrad von Hallstadt, Paul Päurl von Wien und Peter Pachmüller (S. Z a c h o r o w s k i, Consilia, S. 181-182).

${ }_{55}$ Die Edition siehe ebenda, S. 192-201, Nr. 2-6.

${ }^{56}$ Ebenda, S. 197, Nr. 3: concluditur, quod imperialis maiestas a superna collata clemencia nequaquam a facto coronacionis sedis apostolice dependet nec sumpsit exordium et quod citra huiusmodi coronacionem electo canonice in regem Romanum competit omnis iurisdiccio et totalis potestatis imperialis plenitudo ex sola eleccione absque coronacione, que non ad tribuendam vel augendam potestatem, sed ad imperialem dignitatem decorandam extitit adinventa.

${ }^{57}$ Ebenda, S. 198-199, Nr. 5: utrum pro facto regalis coronacionis auctoritas sedis apostolice requiratur et presertim, si in actu coronacionis consecracio et uncio intervenire procurarentur. - - Concluditur - - huiusmodi consecracionem cum unccione non ad necessitatem vel substanciam requiri, sed solum ad regalem dignitatem ornandam et sacris misteriis decorandam; unde actus huiusmodi coronacionis sola imperiali auctoritate poterit explicari nec erit super hoc quavis ex causa sedes apostolica requirenda vel aliter consulenda.

${ }^{58}$ Ebenda, S. 199, Nr. 5: Non facit dubitacionem, quod unccio et consecracio non sint temporalitatis et per consequens imperiali dignitati propria, sed ad ecclesiasticam et pontificalem dignitatem certissimo pertinencia.

${ }_{59}$ Ebenda, S. 201, Nr. 6: cum non sit de casibus specialiter reservatis domino nostro pape.

${ }^{60}$ Ebenda: dicimus, quod salvis consuetudinibus et reservacionibus Romane ecclesie, si que sunt, que nos latent, unccio regum inferiorum ab imperatore ad ordinarios locorum pertinent de iure communi. 
Großfürsten, nötigenfalls von einem eigenen Prälaten oder dem zuständigen Ortsbischof geweiht und gesalbt zu werden ${ }^{61}$. Überdies führte er auch einige Beispiele für abendländische Herrschern an, die ohne Salbung zum König gekrönt worden seien ${ }^{62}$.

Es ist kaum zu ermitteln, ob Witold durch diese Erläuterungen in seiner Absicht, die königliche Krone von Sigismund zu empfangen, genügend bestärkt wurde. Was ihn aber in seinem Denken und Handeln wohl noch bedeutender beeinflusste, war die Verzögerung jener feierlichen und umfangreichen Gesandtschaft, die die königlichen Kronen nach Litauen bringen sollte. Anfang Juli 1430 versicherte Sigismund wiederholt dem Großfürsten, dass die Gesandten aus Ungarn und Böhmen schon vorbereitet seien, die Boten des Reiches ebenso bestimmt würden und die erwünschten königlichen Kronen sicher und unfehlbar (indubie et infallenter) bis zum 8. September (festum Nativitatis Beate Marie Virginis) in Litauen eintreffen würden ${ }^{63}$.

Zuvor aber entschied Sigismund, zwei seine Höflinge und Diplomaten, nämlich Baptista Cigala, den Autor eines der erwähnten juristischen Gutachten, und den Schlesier Sigismund Roth nach Litauen zu entsenden, damit sie Witolds ungeklärte Fragen beantworten, alle seine Bedenken zerstreuen und vor allem wichtige Urkunden und Unterlagen mitbringen sollten ${ }^{64}$. Sie brachen am 4. Juli aus Wien auf und

${ }^{61}$ Der Brief von Sigismund an Witold vom 3. oder 4. Juli 1430, Wien (CEV Nr. 1424): Satis carissime frater V. F. prius expressimus, quod huiusmodi inunccionis et consecracionis non sunt de necessitate materie, sed solum de sollempnitate et cerimoniis, nec oportet, ut super talibus pappalis auctoritas quomodolibet requiratur, nisi quis ex superhabundanti facere vellet, et hoc facta coronacione huiusmodi fieri posset, si vestre fraternitati placent. Et quamquam de illis nullum geramus dubium, nichilominus dum hunc locum Wyennen[sem] intravimus, omnes doctores et iurisperitos huius alme universitatis in hoc facto consultos habuimus, qui concorditer in opinione una concurrunt, videlicet quod unccio et consecracio nullatenus in regis coronacione et creacione requirantur nec sit usquequaque necessaria. Que tamen si affectatur in regibus inferioribus ab imperatore, ad ordinarios locorum pertinet de iure communi, sic quod in re ista non oportet dominum nostrum consulere, sed pocius aliquis vester prelatus et precipue ordinarius vester, hanc unccionem, si eam affectatis, potest peragere.

${ }_{62}$ Ebenda, Nr. 1424: Nichilominus V. F. regiam dignitatem nomen et auctoritatem non debet respuere, cum multi christianorum reges existant eciam antiquissimi similiter et moderni, qui non unccione sed sola coronacione fruuntur, prout est rex Castelle, qui vocatur Hispanie, similiter reges Scocie et Cecilie seu Apulie et multi alii.

${ }^{63}$ Ebenda: assecuramus, quod coronas regias V. F. et illustri consorti vestre preparatas, quas aptas habemus, vobis super prefato festo nativitatis Marie virginis [8. September] indubie et infallenter transmittemus, nisi mors que eciam quorumcumque principum cervices deflectit, quod absit, id surriperit. Habemus enim iam nunccios regnorum nostrorum Hungarie et Bohemie paratos, et de sacro imperio similiter iam disponimus ad quos eciam iam ducere gressus nostros dirigimus. Ursprünglich hätte die Krönungszeremonie schon am 15. August (Mariä Himmelfahrt) stattfinden sollen, doch nach Jan Długosz sei der Termin wegen der Verzögerung der Gesandtschaft auf 8. September verlegt worden, siehe Joannis Dlugossii Annales, lib. XI, S. 285.

${ }^{64}$ CEV Nr. 1424: mittimus - - unum de doctoribus nostris, solempnem de numero oratorum nostrorum, quos cum coronis mittemus, qui cum Sigismundo Roth cras iter arripiet per partes Almanie, nam nunciis nostris per Poloniam ad V. F. nullatenus patet accessus -quousque ambasiatores nostros cum coronis ituros totaliter ad iter ponemus, qui extunc illos precedet et $V$. F. de singulis negociis lucidius informabit. Siehe auch den Brief vom 7. Juli 1430 in CEXV II, Nr. 181: mittimus [d. h. der Römische König] ad eandem vestram fraternitatem wenerabilem et egregiem utriusque iuris doctorem Baptistam Czigwila [sic!], militem 
beabsichtigten, über den so genannten „Markgrafenweg“ zu reisen, der damals die Neumark mit dem Ordensstaat durch das polnische Gebiet verband. Cigala, Roth und ihre Gefolgschaft wurden aber von Jan Czarnkowski, dem späteren Unterkämmerer von Posen, irgendwann vor dem 19. August beraubt und ihre Pferde, Dokumente und einige Wertsachen beschlagnahmt. Nur zwei Pferde wurden ihnen für jeweils einen Boten belassen. Sie gelangten über Schlochau (pol. Człuchów), wo der dortige Komtur die Beraubten ausreichend versorgte, und Preußisch Stargard (pol. Starogard Gdański) nach Marienburg und setzten dann die Reise weiter nach Litauen fort ${ }^{65}$.

Die beschlagnahmten Dokumente seien dem polnischen König vorgelegt worden, der aus deren Inhalt erfahren hätte, dass eine Folgegesandtschaft mit den Kronen zum Aufbruch auf die Reise durch polnisches Gebiet vorbereitet gewesen sei $^{66}$. Deshalb ordnete Jagiełło an, alle Wege aus der Neumark nach Großpolen mit höchster Aufmerksamkeit zu überwachen. Letztendlich haben sich die entsprechenden Maßnahmen effektiv ausgewirkt, weil diese die Gesandtschaft des Römischen Königs daran hinderten, die Oder zu überqueren.

Die königlichen Gesandten hätten sich nämlich in Frankfurt an der Oder versammeln sollen. Noch am 9. September 1430 berichtet der Vogt der Neumark dem Hochmeister von einigen mittlerweile dort eintreffenden Gesandten Sigismunds, unter denen die Herzöge Přemysl von Troppau und Ludwig von BriegLiegnitz waren. Sie hätten auf Erzbischof Günther von Magdeburg und einen gewissen Herzog von Rosenberg (?) gewartet. Ohne sie mangelte es offensichtlich

consiliarium nostrum et unum ex ambasiatoribus, quos cum coronis regiis ad vestram fraternitatem mittimus, qui vos tamquam iuris peritus et in hiis rebus multum imbutus de omnibus vive vocis oraculo debebit et sciat informare et eciam suggerentibus contrarium per viam se veritatis opponere, quem precamur velitis diligenter audire et sibi in dicendis nostri pro parte fidem credulam per omnia adhibere.

65 Über den Überfall wird im Brief des Komturs von Schlochau vom 19. August 1430 an den Hochmeister berichtet (CEV Nr. 1433: „Des allir irluchesten herrn Romischen koniges und unsers gnedigen herrn Wytowds sendeboten sind gekommen ken Slochow [pol. Człuchów] in gebunge dises briffes. Si sint gewund, geslagen unde beroubt, alle ir pferd sind in genomen, sundir czwer pferd haben in die Polen wedirgegeben, iclichin boten ein pferd, di andir louffen alle czu fusze; ir knecht in is genomen nicht obirich kostliche gobe. Sundir des herrn koniges von Ungern ist genomen an golde, cleinod, buchir und cleidir also ghud also tusend dogkathen. Ich wil si euwern gnaden senden nicht czu fusze sundir czu waghene und czu pferd, das si nicht sullen czu fusze komen. Wo si czu euwern gnaden sullen komen, das mag in euwir gnode undir oghen schriben. - - Ich wil si morgen senden ken Stargard anvorsumplich. - - In ist die crone nicht genomen, si haben ir nicht gehad, sundir andir dri sendboten di komen noch hernoch, di sollen di krone bregen"), und Joannis Dlugossii Annales, lib. XI, S. 286: nuncii Baptista et Sigismundus Roth dum Saxonie terris superatis Prussiam ingredi deberent, in custodes et gentes regis per--Ioannem Czarnkowski ordinatas et locatas facientes excubias, incidunt et capti, omnibus literis, quas ferebant, armis et equis exuti, sponsione facta, quod se in Czarnkow pro certo die representaret, parum prudenter dimissi, quod iustum erat in profundam caliginem carceralem detrudi.

${ }^{66}$ Joannis Dlugossii Annales, lib. XI, S. 286-287: Wladislaus Polonie rex apertis fractisque literis, quas ad eum prefatus Czarnkowski in Andrzeiow detulerat, summa diligencia continenciam earum singillatim recensebat. - - At quoniam ex literis Sigismundi regis Romanorum taliter interceptis certum erat nuncius notabiles tum ex parte Imperii tum ex parte Hungarie et Bohemie regnorum cum coronis per Saxoniam versus Prussiam transitum facturos. 
an einer führenden Gestalt. Gleichzeitig warnte der Vogt die Gesandten vor dem Betreten polnischen Bodens wegen der strengen Überwachung der Grenze durch das polnische Heer ${ }^{67}$. Ohnehin hätte die Gesandtschaft ihre Reise vor der Ankunft des Erzbischofs nicht fortgesetzt und demzufolge verbrachte sie dort untätig eineinhalb Monate, bis sie abberufen wurde ${ }^{68}$.

Die chaotische Vorbereitung der Gesandtschaft entsprach nicht der Bedeutsamkeit der projektierten Krönung. Trotzdem bemühte sich Sigismund insbesondere im Briefwechsel bei dem Großfürsten den Anschein zu erwecken, als ob alles für die Krönungsfeier fristgemäß vorbereitet wäre. Die Vertretung Ungarns sei schon im Juli abgeordnet worden ${ }^{69}$, doch den Bischof von Zagreb, den königlichen Kanzler und Diplomaten Johann von Alben, und Herzog Ernst von Bayern entsandte der König aus Nürnberg erst um den Monatswechsel August/September ${ }^{70}$. Einige Angaben deuten sogar darauf hin, dass über die Abordnung der Delegation bereits vor dem 26. Mai entschieden worden war $^{71}$. Die Zusammensetzung dieser Gesandtschaft

${ }^{67}$ Den Brief des Vogts in CEV Nr. 1438. Die Gesandten teilten einem Boten des Vogts mit, dass ,sie beithende sein des herrn bischofes von Maydeburg und des herczogen von Rosenberg“. Eine einwandfreie Identifizierung des hier vorkommenden Herzogs ist nicht ganz vollziehbar. Man darf vielleicht an den böhmischen Adeligen Ulrich von Rosenberg denken, der sich im Sommer 1430 tatsächlich bei Sigismund aufhielt und im Juni vom König sogar ersucht wurde, mit seinen eigenen Gefolgsleuten wegen der Krönung zu ihm zu kommen, siehe Listář a listinář Oldřicha z Rožmberka, Bd. I, hg. von B. Rynešová, Praha 1929, Nr. 175: „A jakož mieníš s padesáti koňmi přijeti k nám i k tomu korunování: věz, že všickni, kteříž pojedú i Němpci i Uhři i kniežata, nemají než po čtyřiceti koních; na ty sě také též móžeš přichystati““. Diese Vermutung bekräftigt auch ein Brief des Thorner Komturs vom 30. Oktober 1430, wo unter den königlichen Gesandten ein ,,von Rossenberg auß Behmen“ genannt wird (С. В. П о л е х о в, Известие хроники, S. 97, Anm. 27). Nichtsdestoweniger ist es auch nicht auszuschließen, dass Sigismunds Aufforderung an Ulrich nicht mit der geplanten litauischen Krönung, sondern mit der damals vorbereiteten Kaiserkrönung Sigismunds in Verbindung stand.

${ }^{68}$ Joannis Dlugossii Annales, lib. XI, S. 287-289; vgl. K. G ó r s k a - G o ł a s k a, Zasadzka rycerstwa wielkopolskiego na drodze margrabskiej pod Turzą Górą w 1430 r., Studia i Materiały do Dziejów Wielkopolski i Pomorza 12, 1976, Heft 1 (23), S. 53-62. Die Krone (oder die Kronen) wurde später mehrmals an vermögende Bürger aus Nürnberg (dort dem Großkaufmann Ulrich Ortlieb für 1500 Gulden) Ravensburg, Basel und Regensburg verpfändet, siehe Wien, Haus-, Hof- und Staatsarchiv, Bestand Reichsregister, Bd. I, fol. 131r, neu: 144r (RI XI, Nr. 8546); Bd. K, fol. 135r, neu: 146 (RI XI, Nr. 10859); vgl. P. J o a c h i m - H e i n i g, Reichsstädte, freie Städte und Königtum 1389-1450. Ein Beitrag zur deutschen Verfassungsgeschichte, Wiesbaden 1983, S. 215; R. P e tr a u s k a s, Korona Witolda, S. 22-23. Trotzdem war eine Meinung unter den litauischen politischen Eliten noch im 16. Jahrhundert verbreitet, dass diese Krone durch den Polen im Jahr 1430 beschlagnahmt und dann in Krakau aufbewahrt gewesen sein soll (J. B a r d a c h, Krewo i Lublin. Z problemów unii polsko-litewskiej, in: Derselbe, Studia z ustroju i prawa Wielkiego Księstwa Litewskiego XIV-XVII w., Warszawa 1970, S. 45).

${ }^{69}$ Den Brief von Stefan Rozgonyi an Witold vom 13. Juli [1430], in dem die ungarischen Gesandten erwähnt sind (CEXV II, Nr. 184).

70 Andreas von Regensburg, Sämtliche Werke, hg. von G. Leidinger, München 1903 (Quellen und Erörterungen zur bayerischen und deutschen Geschichte NF 1), S. 571: Exinde venit [König Sigismund] Nürbergam, ubi Johannem episcopum Zagrabiensem et Ernestum ducem Bavarie misit in Litwaniam ad coronandum ducem Witoldum in regem.

${ }^{71}$ Siehe Anm. 72. 
verdient unsere Aufmerksamkeit, weil ihre Mitglieder eine bestimmende Rolle im Ablauf der erwarteten Krönungszeremonie spielen sollten und zu den einflussreichsten Prälaten und Adeligen des Römischen Reichs und der Königreiche Ungarn und Böhmen gehören sollten. Es ist zwar wegen der verstreuten Quellenangaben kaum möglich, eine einwandfreie vollständige Mitgliederübersicht etwa in Form einer Namensliste zu geben, doch immerhin können wir die folgende Struktur der nach Litauen beorderten Gesandtschaft ermitteln ${ }^{72}$.

Das Römische Reich repräsentierten: der Zagreber Bischof Johann von Alben (gest. 1433), der als Reichskanzler und Großkanzler von Ungarn jahrelang zu den verlässlichen Diplomaten und vertrauten Räten Sigismunds gehörte ${ }^{73}$; der Magdeburger Erzbischof Günther II. Graf von Schwarzburg (gest. 1445) ${ }^{74}$; Herzog Ernst von Bayern-München (gest. 1438) ${ }^{75}$.

Das Königreich Ungarn repräsentierten: Péter Berzevici, königlicher Schatzmeister und Gespan der Zips (gest. 1433) ${ }^{76}$; Laurenz Hédervári, königlicher Stallmeister

72 Die angeführte Liste ist nicht als zweifelsfrei und vollständig zu betrachten. Aus einem undatierten und einem anderem datierten Schriftstück geht hervor, dass wohl auch noch der Erzbischof von Köln und ein weiterer Herzog von Bayern (neben Ernst von Bayern-München) für die Gesandschaft bestimmt wurden; siehe die anonyme, vermutlich aus Ungarn stammende Auskunft an den Ordensprokurator in Rom, Kaspar Wandofen, vom 26. Mai 1430, in: Die Berichte der Generalprokuratoren des Deutschen Ordens an der Kurie, Bd. IV, Halbbd. 1, bearb. von K. Forstreuter, H. Koeppen, Göttingen 1973, Nr. 131: Dux Witawdus coronabitur in regem super festo Nativitatis Marie et ad coronacionem eiusdem dispositi sunt duo duces Bavarie, unus dux Slesie, duo barones Ungarie, duo barones Bohemie et unus episcopus de Ungaria, qui omnes ibunt et portabunt coronas duci et ducisse, und ein anonymes und undatiertes Verzeichnis derjenigen Personen, die Sigismund begleiten sollten, in: Berlin, Geheimes Staatsarchiv Preußischer Kulturbesitz, XX. Hauptabteilung, Ordensbriefarchiv, Nr. 5545: Vestra excellentia voluit nomina baronum cum serenissimo domino nostro rege existencium - -. Item scribuntur nomina eorum, quos serenissimus dominus rex in facto coronacionis ad illustrissimum principem et dominum dominum Wytoudum magnum ducem similiter cum corona excogitavit transmittendos. Primo reverendissimos dominos archiepiscopum de Colonia, si fieri poterit, item archiepiscopum de Magd[e]burg et unum episcopum de Hungaria. Item unum ducem de Bavaria. Item dominum Prziemek, ducem Boznensem [sic!] etc. Item duos barones de Hungaria. Für diese Quellenhinweise danke ich Dr. Mark Whelan herzlich. Eine weitere Liste von Gesandten in einem Brief des Thorner Komturs vom 30. Oktober 1430 (dazu C. В. По ле х о в, Известие хроники, S. 97, Anm. 27).

${ }^{73}$ E. F o r s tre it e r, Die deutsche Reichskanzlei und deren Nebenkanzleien unter Kaiser Sigmunds von Luxemburg, Wien 1924 (Diss. Masch.), S. 14-17; F.-R. E r k e n s, Über Kanzlei und Kanzler König Sigismunds. Zum Kontinuitätsproblem in der deutschen Königskanzlei unter dem letzten Luxemburger, Archiv für Diplomatik 33, 1987, S. 447-449.

${ }^{74}$ M. S c h o l z, Günther, Graf von Schwarzburg (1382-1445), in: Die Bischöfe des Heiligen Römischen Reiches 1198-1448. Ein biographisches Lexikon, hg. von E. Gatz, Berlin 2001, S. 393-394. Dem Erzbischof widmet zwar eine narrative Quelle umgehende Aufmerksamkeit, doch von seiner Teilnahme an der Gesandtschaft nach Litauen erfahren wir so gut wie nichts. Gesta archiepiscoporum Magdeburgensium, hg. von W. Schum, in: Monumenta Germaniae historica, Scriptores, Bd. XIV, Hannoverae 1883, S. 455-466.

${ }^{75}$ G. S c h w e r t 1, Ernst, Herzog von Bayern-München (1373-1438), in: Lexikon des Mittelalters, Bd. III (1986), Sp. 2177.

${ }^{76}$ Joannis Dlugossii Annales, lib. XI, S. 287: Petrus Iugo filius Henrici tavernicorum regalium magister; CEXV II, Nr. 184: Petrus filius Henrici magister tavernicorum regalium. 


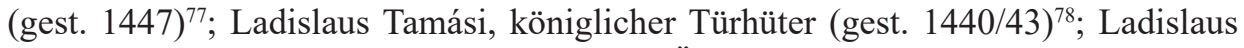
Kanizsai (gest. 1434), Gespan des Komitats Ödenburg und Bruder des Erzbischofs Johann von Gran ${ }^{79}$; Paulus Waldwardi (?) ${ }^{80}$.

Das Königreich Böhmen (einschließlich der schlesischen Herzöge) repräsentierten: Herzog Přemysl von Troppau ${ }^{81}$; Herzog Ludwig von Brieg-Liegnitz ${ }^{82}$; Puta der Jüngere von Častolowitz ${ }^{83}$; Ulrich von Rosenberg (?) ${ }^{84}$.

Anfang September bekam Witold Nachricht von der aussichtslosen Lage der königlichen Gesandten, nachdem Cigala und Roth an seinem Hof eingetroffen waren. Darauf entschloss er sich wiederum, die Krönungsfeierlichkeiten, zu denen er schon manche Fürsten und Würdenträger eingeladen hatte ${ }^{85}$, auf den 29. September (Michaelis) zu verschieben ${ }^{86}$. Als die Gesandtschaft mit den Kronen Litauen auch $\mathrm{zu}$ jenem Zeitpunkt nicht erreichte ${ }^{87}$ und der polnische König sich im Gegenteil mit Witold aussöhnte, adressierte der Großfürst an Sigismund ein Schreiben, in denen er wohl freiwillig auf die Erhebung zum König verzichtete ${ }^{88}$.

Er gehörte zu den königlichen familiaribus et consiliariis, siehe J. K. H o e n s c h, Kaiser Sigismund. Herrscher an der Schwelle zur Neuzeit 1368-1437, Darmstadt 1997, S. 122.

77 Joannis Dlugossii Annales, lib. XI, S. 287: Laurencius de Hedrewar agazonum regalium magister; CEXV II, Nr. 184: Laurencius de Hindemwer agazonum regalium supremus magister.

${ }_{78}$ Joannis Dlugossii Annales, lib. XI, S. 287: Ladislaus ianitorum regalium magister; CEXV II, Nr. 184: Ladislaus filius Weiprod ianitorum regalium summus magister.

${ }^{79}$ CEXV II, Nr. 184: Ladislaus filius Swan de Kanisso frater idem reverendissimi in Christo patris domini Johannis archiepiscopi Strigoniensis.

${ }^{80}$ Nicht identifizierbar (evtl. Verschreibung für Udvardi?). CEXV II, Nr. 184: Paulus Waldwardi similiter est electus.

81 Joannis Dlugossii Annales, lib. XI, S. 287: ex parte Regni Bohemie dux Przemko Oppawiensis. Vgl. weiter M. Č a p s ký, Vévoda Přemek Opavský (1366-1433). Ve službách posledních Lucemburků, Brno-Opava 2005, S. 288-289.

${ }^{82}$ CEV Nr. 1438; vgl. F. S z a fr a ń s k i, Ludwik II brzesko-legnicki, feudał Śląski z doby późnego średniowiecza, Wrocław 1972, der keine Kenntnis von der Teilnahme des Herzogs an der Gesandtschaft hat.

${ }^{83}$ Joannis Dlugossii Annales, lib. XI, S. 287: Potha de Pothenschen Bohemus; CEXV II, Nr. 184: de Bochemia Postpotam (sic!).

${ }^{84}$ Dazu siehe Anm. 67.

${ }^{85}$ Namentlich wurden der Großfürst Wassili II. der Blinde von Moskau, der ein Enkel Witolds war, der Großfürst Boris von Twer, ein unbekannter Fürst von Odoiew (1407 war diese Burg vom litauischen Heer erobert worden), der Hochmeister Paul von Rusdorf und einige der bedeutenderen Komture sowie der Khan der Goldenen Horde, Sayid Ahmed I., eingeladen (Joannis Dlugossii Annales, lib. XI, S. 285-286: dux Withaudus plures principes Russie, videlicet Mosquensem, Tiverensem, Odoyewiensem, magistrum et principaliores commendatores Prussie et Tartarorum imperatorem invitaverat).

${ }^{86}$ CEV Nr. 1439, 1444.

${ }^{87}$ Die Gesandten Cigala und Roth hätten Witold ermahnt, die fehlenden königlichen Kronen in Litauen herstellen zu lassen und mit diesen sich selbst und dessen Gattin krönen zu lassen. Eine solche Krönung hätte Sigismund außer Zweifel bestätigt (Joannis Dlugossii Annales, lib. XI, S. 291: presens enim in Lithuania Baptista doctor et Sigismundus Roth aderant, qui monere, sollicitare ducem Withaudum non desistebant, ut coronis in Vilna fabricatis coronari se permitteret, cum huiusmodi coronacionem Romanorum rex Sigismundus esset ratificaturus).

${ }^{88}$ In einem Brief vom 13. Oktober 1430 beteuerte Witold, die Krone empfangen zu wollen, jedoch erst nach Zustimmung der Polen. Daneben bat er Sigismund, die Krönungskleinodien 


\section{DIE KRÖNUNGSURKUNDE UND -ZEREMONIE}

Für den Römischen König bedeutete jedoch die Umwandlung des Großfürstentums Litauen zum Königreich einen unentbehrlichen Schritt zum erstrebten Bündnisabkommen zwischen jenem Territorium und dem Römischen Reich, dem Ordensstaat, Böhmen sowie Ungarn, sodass weder der Verzicht Witolds noch dessen Tod am 27. Oktober 1430 dieses langfristige politische Vorhaben verhindern sollten. Sigismunds Absichten widerspiegeln sich sowohl in der Zusammensetzung der repräsentativen Gesandtschaft, als auch in den von den Polen beschlagnahmten Dokumenten, deren Inhalt glücklicherweise, wenn auch nur teilweise, überliefert ist.

Unter den verfügbaren Quellen sind folgende Schriftstücken teils im Wortlaut, teils lediglich als Erwähnung erhalten geblieben: die Krönungsurkunde, die Instruktion für die Gesandtschaft zum Abschluss des Bündnisabkommens, der Entwurf desselben Abkommens, die juristischen Gutachten von Baptista Cigala und den Wiener doctores decretorum sowie die Krönungsordnung (processus coronacionis) ${ }^{89}$. Sowohl die Krönungsurkunde als auch die Instruktion für die Gesandten wurden bislang in der Forschung wenig beachtet, zu Unrecht, da beide Schriftstücke für die Einschätzung

gegebenfalls mit einer deutlich bescheideneren Gefolgschaft zu entsenden (CEV Nr. 1456: Preterea de consensu coronacionis nostre idem dominus rex [Władysław Jagiełło] asserebat, se nobiscum hic concludere non posse differens ad consiliarios suos, et misit in continenti nuncios suos ad regnum Polonie, pro consiliis et responsis ipsorum; sit tamen quod sit, non obtulimus nos nec offerimus ad non recipiendum huiusmodi coronas. Unde si adhuc placuerit $V$. S., potestatis easdem nobis transmittere non tamen cum tanta comitiva et tantorum ac tot ambasiatorum ac signanter ducum et tali diwlgacione transitus eorum, sed secreciori modo per pauciores oratores poteritis tantum efficere). Zwei Tage später ersuchte Witold die Gesandten von Sigismund, polnischen Boden nicht zu betreten, bis eine Einigung zwischen ihm und Jagiełło zustandegekommen wäre, was de facto mit einer Ermahnung zur Rückkehr gleichzusetzen ist (CEV Nr. 1458: Quare V. S. petimus amicabiliter, postulantes, quatenus $S$. $V$. dictos ambasiatores vestros non confortaret nec eos ad presens ita prout proposuit transmitteret ad nos, donec $V$. S. iterum per nuncios vel litteras nostras desuper avisata et interim eciam consiliari - - domini regis de Polonie partibus sibi consilia eorum poterunt rescribi de consensu nostre huiusmodi coronacionis, quam ita cum fratre nostro domino rege speramus ad bonum finem et unionem devenire, quod postmodum dicti ambasiatores - - et per regnum Polonie secure poterint pertransire). Vgl. auch den Brief vom selben Tag an den Hochmeister (CEV Nr. 1459).

${ }^{89}$ Jan Długosz erwähnt ausdrücklich drei Dokumente (Joannis Dlugossii Annales, lib. XI, S. 287): Multe admodum erant litere tum secrete tum patentes, quibus creacio ducis Withaudi in regem Lithuanie [die Krönungsurkunde], processus omnis coronacionis et unccionis Withaudi et consortis sue Iuliane in regem et reginam [die Krönungsordnung] et liga perpetua Regnorum Hungarie et Bohemie cum Lithuania, Cruciferis de Prussia et Livonia in societatem [das Bündnisabkommen] huiusmodi receptis, continebatur. In der Handschrift, die höchstwahrscheinlich im Auftrag vom Bischof Zbigniew Oleśnicki von Krakau entstanden ist und heute in Kraków, Biblioteka Książąt Czartoryskich, Ms. 233 aufbewahrt wird, befinden sich die folgenden Schriftstücke: die Gutachten von Baptista Cigala (S. 399-401) und der Wiener Gelehrten (S. 401-403), die Instruktion für die Gesandten (S. 403-409) und die Krönungsurkunde (S. 409-412). Neben diesen stehen noch weitere Unterlagen, die mit der Sache zusammenhängen, wie das Gutachten der Krakauer Juristen, die polnische Appellation, die politische Korrespondenz usw. Eine ausführliche Handschriftbeschreibung bietet die Einleitung in: CEXV II, S. X-XVIII. Vgl. G. B ł a s z c z y k, Burza, S. 137. 
der politischen Konzeption des Römischen Königs Quellen von erheblicher Bedeutung darstellen ${ }^{90}$.

Die undatierte ${ }^{91}$ Krönungsurkunde ist in zwei Fassungen mit jeweils unterschiedlichem Umfang überliefert ${ }^{92}$. Die Abschrift der kürzeren Version befindet sich in einem Formelbuch aus den siebziger Jahren des 15. Jahrhunderts ${ }^{93}$, während die längere Version, die wohl nach der beschlagnahmten Urkunde selbst abgeschrieben worden war, angeblich schon um 1433 entstanden ist ${ }^{94}$.

Schon der flüchtige Vergleich des Inhalts beider Fassungen führt zu merkwürdigen Ergebnissen. Die Arenga sowie Narratio sind mit einer kleinen Ausnahme vollkommen gleichlautend ${ }^{95}$. Bedeutende Abweichungen kommen erst in der Dispositio vor, wobei die Nachträge in der Melker Abschrift im Gegenteil zu denjenigen in der Krakauer Version den Inhalt nicht elementar verändern. Dagegen sind drei Abweichungen in der Krakauer Fassung von grundsätzlicher Bedeutung (siehe unten).

Aus der Überlieferung und dem Inhaltsvergleich ist die Beziehung beider Fassungen untereinander kaum zu ermitteln. Ob die kürzere Version einen Entwurf darstellt, der ursprünglich mit Witold verhandelt, dann aber endgültig abgelehnt wurde, oder ob diese Fassung überhaupt zur Verhandlung kam, ist nicht zu beurteilen. Mit großer Sicherheit darf man nur vermuten, dass die längere Version als der endgültige Wortlaut für den Großfürsten vorgesehen war, obwohl der Text Litauen letztendlich gar nicht erreichte. Auch aus diesem Grunde ist die Krönungsurkunde zusammen mit der Instruktion für die Gesandtschaft eine unersetzliche Quelle vor allem für die Beurteilung des Rechtsstandes des neu zu errichtenden Königreichs und der geplanten Krönungszeremonie.

${ }^{90}$ Vgl. G. M i c k ū n a it è, Making, S. 75-76, die sich mit der Gesandtschaftsinstruktion befasst.

${ }^{91}$ Es kann nur die Datierung ante quem festgelegt werden. Die Urkunde muss vor dem 4. Juli 1430, dem Tag, an dem die Gesandten mit den Dokumenten aufbrachen, mundiert und ausgestellt worden sein.

${ }_{92}$ Siehe Anhang.

${ }_{93}$ Melk, Stiftsbibliothek, Sign. 780/1, fol. 45v-46v (p. 90-92). Eine Edition fehlt. Fast die ganze Handschrift wurde durch eine einzige Schreiberhand geschrieben und im 19. Jahrhundert in zwei Bände geteilt (Bd. 1: fol. 1-202; Bd. 2: fol. 203-393). Die Blätter 6v bis 103v umfassen Formeln, welche größtenteils aus dem Collectarius perpetuarum formarum Johannis de Gelnhausen und der Summa cancellariae stammen, insgesamt 134 Formeln aus Kanzleien der Römischen Könige, davon 102 von Karl IV., 7 von Wenzel IV., 24 von Sigismund von Luxemburg und eine von Albrecht II. von Habsburg; eine ausführliche Beschreibung der Handschrift siehe bei Ch. Glas s ner, Katalog der deutschen Handschriften des 15. und 16. Jahrhunderts des Benediktinerstiftes Melk. Katalog- und Registerband, Wien 2016, S. 308-328, bei der ich mich für die Übermittlung der Kopien der obenstehenden Handschrift herzlich bedanken möchte.

${ }^{94}$ Kraków, Biblioteka Książąt Czartoryskich, Ms. 233, S. 409-412. Im Vergleich zu jener vorgenannten Abschrift, die ebenfalls nicht fehlerfrei ist, ist diese deutlich lückenhafter und fehlerbehaftet. Ed.: CEXV II, Nr. 182 (ohne Kenntnis der Abschrift in Melk). Zur Datierung der Handschrift siehe ebenda, S. XVII-XVIII.

${ }^{95}$ In der Krakauer Version werden zusätzlich jene Heidenvölker benannt, welche der Großfürst zum Christentum bekehrt habe (CEXV II, Nr. 182): precipue tamen gentem Lithwanicam et Samagiticam, tamquam apostolus Domini sua diligencia primitus convertit. 
In der stark narrativen Arenga wird die Notwendigkeit der Herrschaft der weltlichen Machthaber (principes et reges) theologisch begründet. Nachdem die vom Schöpfer für die Ewigkeit prädestinierte Menschheit durch deren Ungehorsam in Verfall geraten war, hätten sich das Übel und die Ungerechtigkeit unter den Menschen in den nachfolgenden Generationen dermaßen vermehrt, dass es unumgänglich geworden sei, Herrscher über die Völker (gentibus) zu setzen, um Zwiespalt zu überwinden, die Bösen zu bestrafen und umgekehrt die Guten zu belohnen.

In der anschließenden Narratio werden konkrete Gründe für die Erhebung Witolds zum König angegeben. Der Großfürst wird als ein wahrer Apostel der heidnischen Völker Osteuropas (vor allem der Litauer und der Samaiten) dargestellt, der ad fidei christiane votivum augmentum plurimos gentes barbaras, precipue tamen gentem Lithwanicam et Samagiticam, tamquam apostolus Domini sua diligencia primitus convertit ad fidem et lavacro felicis baptismatis Spiritus Sancti gratia disponente sacravit, manche Kirchen gegründet und die Kleriker großzügig beschenkt, sich aber mit den ihm durch die Gnade Gottes geschenkten Gebieten nicht begnügt habe, sondern den katholischen Glauben auch in den Nachbarländern verbreiten haben wollen ${ }^{96}$. Um ihn in diesem Eifer zu unterstützen, habe Sigismund aus eigenem Antrieb entschieden, Witold und dessen Nachkommen die königliche Würde $\mathrm{zu}$ verleihen.

Die Dispositio enthält drei nur in der Krakauer Abschrift vorkommende Punkte, in welchen Sigismund 1) dem Großfürsten die Unabhängigkeit vom Römischen König sowie vom Reich und jeglichen anderen Herrschern bestätigt ${ }^{97}$, 2) seine Gesandten bevollmächtigt, Witold und dessen Gattin zum König bzw. zur Königin zu krönen ${ }^{98}$, und 3) demselben Großfürsten das Privileg verleiht, sein Wappen und das des neu geschaffenen Königreichs Litauen nach eigenem Belieben beibehalten, verändern

${ }^{96}$ Die Verdienste Witolds und Jagiełłos in der Bekehrung der Heiden zum katholischen Glauben wurden auch vom Papst gewürdigt, als Johannes XXIII. beide Herrscher schon 1415 zu Generalvikaren für Nowgorod und Pskow ernannte (CEXV II, Nr. 58) und Martin V. dieselben zur Rückführung der Hussiten in die Kirche bevollmächtigte (Joannis Dlugossii Annales, lib. XI, S. 262: Nam si gentes natas et inveteratas in errore idolatrarum gentilium zelo fidei reduxisti ad rectum cultum Dei, quanto facilius vel reduces vel confundes eos, qui nati et educati in vera religione Christiana). Martin V. hob Witolds Verdienste in der Christianisierung sogar in jenem Brief hervor, durch welchen er ihn von der Krönung abbringen wollte (ebenda, S. 275: Nos enim te propter excellenciam tuam et bona eximia et singularia, que fecisti in propagacione fidei Christiane, magni facimus probitatem tuam et te paterna caritate diligimus ac dignitate regia dignissimum iudicamus, sed vellemus personam tuam cum pace, sine scandalo, sine iniuria et sine discordia fratris tui talibus ornamentis ornari).

${ }^{97}$ CEXV II, Nr. 182: quod ex honore, quem vobis libenter edicimus, nichil libertatis vobis et regno vestro obstruatur, quin ymo sicut actenus vestra serenitas dux liber extiterat, sic imposteri regio decorata decore vos et successores vestri reges liberi nec nobis, nec sacro imperio, nec cuicunque alteri subditi seu vasalli, sed solum ut cristianorum in illis finibus clipeus [contra] gentiles insultus coadiutores [ms. quoadiutores] persistatis.

${ }_{98}$ Ebenda: hic presentes, videlicet A. B. C., pro nobis et sacro imperio, a quo huiusmodi coronacionis auctoritas tamquam a mundi monarchia procedit, plenum mandatum et facultatem ad coronandam vestram celsitudinem et illustrissimam consortem vestram habentes, quam potestatem et facultatem ipsis damus et tribuimus presencium per tenoris vigorem. 
oder bessern zu dürfen"99. Der einheitliche Grundgedanke dieser drei „Säulen“ besteht vor allem in der Souveränität Litauens, auf welcher das neue Königtum wesentlich beruhen soll.

Der Großfürst betrachtete sich selbst nämlich stets als liber dux, eine Ansicht, die Sigismund jetzt nicht nur bestätigte, sondern auch dadurch erweiterte, dass Witold nun als König, und dessen Nachfolger als Könige weder dem Römischen König, noch dem Heiligen Reich, noch wem auch immer untertänig sein sollten. Dies war in der Tat die brennende Streitfrage zwischen Jagiełło und dem polnischen Adel einerseits und Witold anderseits, der sich darüber mehrmals in der Korrespondenz äußerte. Der Großfürst empfand selbst die geringste Andeutung seiner Abhängigkeit oder die Infragestellung seiner Souveränität als schwere Beleidigung ${ }^{100}$. Demgegenüber sahen die Polen in der litauischen Krone die Zerstörung der in Horodlo 1413 abgeschlossenen Union zwischen Polen und Litauen. Im Vertrag wird explizit betont, dass eine solche Union perpetuis temporibus irrevocabiliter et irrefregabiliter semper sein solle ${ }^{101}$. Die Union hatte eine kollektive polnisch-litauische Abstimmung über einen Nachfolger im Fall des Todes ohne Nachkommen gleichermaßen im Königreich sowie im Großfürstentum vorgesehen, ein Vorsatz, der aber durch die Erhebung Litauens zum Königtum ebenfalls verletzt wurde ${ }^{102}$.

Die zweite „Säule“ stellt die den Beauftragten verliehene Vollmacht dar, die Krönung in Vertretung des Römischen Königs sowie des Heiligen Reiches, das die Autorität dazu gleichsam als eine Weltmonarchie besitze (pro nobis et sacro imperio, a quo huiusmodi coronacionis auctoritas tamquam a mundi monarchia procedit), durchzuführen. Sigismund bekannte sich dadurch zur konstantinischen Auffassung seiner Regierung und Herrschaft. Er trat besonders während des Konzils von Konstanz

99 Ebenda: addicientes et dantes V. F. arbitrium liberum et plenariam potestatem, quod arma seu insignia $v$ [estra] et regni vestri, que veri predecessores magni duces Lithwanie et vestre serenitatis hucusque gestare soliti estis, retinere vel in quamcumque formam [ms. favorem] aliam vobis placabilem inmutare [ms. invitare] et meliorare possitis, sicut plerique alii reges cristianorum hucusque fecerunt et sicut vobis melius videbitur expedire.

${ }^{100}$ Den Brief vom 17. Februar 1429 (Witold an Jagiełło) siehe in: CEV Nr. 1345; den Brief vom Juni 1430 siehe in: CEV Nr. 1358: [Witold] cogitare primo incepimus et cum subditis nostris desuper tractare, quomodo confusionem et illibertatem, quibus ipse dominus rex Polonie nos et terras nostras innodare et opprimere niteretur, evadere possemus, cum nunquam alias illiberi fuissemus, pro quo apud eundem dominum regem Polonie instetimus et laboravimus, ut sicut nos illiberos esse propalavit, quod nos ita liberos fore manifestaret. Den Brief vom 14. Mai 1430 (Witold an Jagiełło) siehe in: CEV Nr. 1353: nosque - - illiberos esse difamastis.

$1011413 \mathrm{~m}$. Horodlès aktai (dokumentai ir tyrinejjimaj) / Akty horodelskie z 1413 roku (dokumenty i studia), hg. von J. Kiaupienè, L. Korczak, Vilnius-Kraków 2013, S. 37-42, hier S. 38. Zur Bedeutung der Union von Horodlo siehe: Unia w Horodle na tle stosunków polsko-litewskich. Od Krewa do Zaręczenia Wzajemnego Obojga Narodów, Warszawa 2015.

1021413 m. Horodlès aktai, S. 40: quod predicti barones et nobiles etc. Littwanie post mortem Allexandri alias Witowdi magni ducis moderni nullum habebunt aut eligunt pro magno principe et domino Littwanie, nisi quem rex Polonie vel ipsius successores cum consilio prelatorum et baronum Polonie et terrarum Littwanie duxerint eligendos, statuendos et locandos. Sic similiter prelati, barones et nobiles Regni Polonie, rege Polonie sine liberis et successoribus legittimis decedente, regem et dominum non debent ipsis eligere sine scitu et consilio nostro, videlicet Allexandri magni ducis baronumque et nobilium terrarum Littwanie. 
als ein „neuer“ Konstantin auf, wobei der Genueser Erzbischof Pileus (gest. 1433) in seiner Rede vor dem Römischen König Kaiser Konstantin als Maßstab evozierte ${ }^{103}$. Überdies war Sigismunds Privatkapelle wahrscheinlich mit einem bis heute erhaltenen Textilstück ausgestattet, das mit den in Gold gestickten und mit vier gleichlangen Armen gestalteten Flammenkreuzen geziert wurde. Dieses (Ab-)Zeichen, das wohl nicht unabhängig vom Siegeskreuz Konstantins des Großen und anläßlich der Schlacht bei Nikopolis entstanden war, wurde nachweislich 1416 in Paris von Sigismund und seiner Gefolgschaft an ihren Gewändern getragen ${ }^{104}$.

Die Tatsache, dass Sigismund offensichtlich an antike kaiserliche Traditionen auch im Anspruch auf die Kronenverleihung anknüpfte, bedeutet jedoch nicht, dass er mit dem Papst darum rivalisierte ${ }^{105}$. Es fällt auf, dass Papst Martin V. selbst die Argumentation über seine Prärogative zur Kronenverleihung aus dem polnischen juristischen Gutachten gar nicht übernahm. Seine Missbilligung der Krönung begründete er in seinen Briefen an Sigismund ${ }^{106}$, Witold ${ }^{107}$ und den Bischof von Kulm ${ }^{108}$ ganz anders und zwar dadurch, dass diese die schon abgeschlossenen Verträge zwischen Polen und Litauen, aber auch zwischen Jagiełło und Sigismund verletzen würde und zu einem blutigen Krieg unter den Christen führen könnte. Der Papst bestritt also nicht die Krönungsbefugnis Sigismunds, befürchtete aber die unerwünschten Folgen, die solche Schritte zeitigen könnten. Ebenso bagatellisierte Sigismund die Notwendigkeit der päpstlichen Bewilligung zur Krönung Witolds nicht deshalb, weil er die Kirchensalbung und -weihe gering geschätzt oder als ganz entbehrlich betrachtet hätte. Er war sich bloß dessen bewusst, dass sein Krönungsplan unter der bestehenden politischen Konstellation beim Papst nicht durchsetzbar gewesen wäre. Die respektvolle Rivalität zwischen den beiden damaligen Universalmächten bestand prinzipiell in den unterschiedlichen Ansichten zu Kirchenreform und Hussitenfrage.

Die dritte „Säule“ stellt das Privileg dar, dass Witold sein Wappen (arma seu insignia) und jenes des Landes, wie die vorangegangenen Großfürsten es bisher gebraucht hätten, beibehalten oder nach eigenem Belieben verändern bzw. bessern dürfte. Das litauische Wappen hatte sich aus dem unter den litauischen Fürsten beliebten Siegelbild entwickelte, das einen gerüsteten Reiter mit gezogenem Schwert darstellt ${ }^{109}$. Die Reiterfigur, die das heraldische Symbol des Landes Litauen sowie

${ }^{103}$ H. J. M i e r a u, Kaiser und Papst im Mittelalter, Köln-Weimar-Wien 2010, S. 25.

104 Sigismundus Rex et Imperator (wie Anm. 32), S. 342-343, Nr. 4.43. Das Abzeichen wurde nicht nur in Paris gebraucht, siehe die Miniaturen in einer Handschrift der Chronik von Ulrich von Richental von 1460-1464, in: Praha, Národní knihovna České republiky, Sign. XVI A 17, fol. 125r, 126rv, 129r, 131r, 132r, 134r, 154r, 165rv.

105 Vgl. H. H i r s c h, Das Recht der Königserhebung durch Kaiser und Papst im hohen Mittelalter, in: Festschrift Ernst Heymann, Bd. I, Weimar 1940, S. 209-249.

106 Joannis Dlugossii Annales, lib. XI, S. 272-273.

107 Ebenda, S. 274-275.

108 CEXV II, Nr. 186. Der Papst verbietet dem Bischof von Kulm, in welcher Form auch immer an der Krönungszeremonie des Großfürsten teilzunehmen. Es ist zu vermuten, dass analoge päpstliche Mandate auch an andere Bischöfe im Ordensstaat und Litauen abgeschickt wurden, vgl. G. Bła s z c z y k, Burza, S. 144, Anm. 502.

${ }_{109}$ M. G u m o w s k i, Pieczęcie książąt litewskich, Ateneum Wileńskie 7, 1930, S. 684725, dessen mangelhafte Behauptungen W. S e m k o w i c z, Sfragistyka Witołda, Wiadomości 
des Wilnaer Bezirks geworden ist, kommt später auf Wappen- und Majestätssiegel Jagiełłos, sowie Witolds als Wappenbild vor ${ }^{110}$.

Die Position dieses Wappenbildes auf den Majestätssiegel beider Vettern verdient unsere Beachtung. In beiden Fällen wird nämlich der thronende Herrscher mit den ihn umgebenden Wappen der jeweiligen von ihm beherrschten Länder und Gebiete dargestellt. Der Unterschied liegt in der Zahl der Wappen: der Gestalt des Königs sind sieben, jener des Großfürsten vier Wappen beigegeben. Jagiełłos Reiterfigur ist deshalb im Vergleich zu der Witolds etwas kleiner ausgefallen. Noch merkwürdiger ist jedoch die Geste des Großfürsten, der das Wappen Litauens in seiner linken Hand hält. Nicht nur diese Geste, sondern auch das Majestätssiegel selbst, das bei nicht gekrönten Fürsten ungewöhnlich war und das Witold von 1407 bis zu seinem Tod gebrauchte, deuten offensichtlich auf fortschreitende Bemühungen des Großfürsten um eine selbstständige Regierung gegenüber Jagiełło hin. Die Herrschaftsinsignien beschränken sich auf die Fürstenmitra auf dem Kopf und das Schwert in der rechten Hand. Wäre Witold wirklich gekrönt worden, hätte er zweifellos die von Sigismund gewährte Wappenverbesserung ausgenutzt ${ }^{111}$.

Um die Zukunft und die Nachhaltigkeit der Erhebung Litauens zum Königtum sicherzustellen, wurde die Königswürde in der Urkunde nicht nur Witolds Nachkommen (heredes et successores), sondern auch dessen Gattin Uljana Olschanski (lit. Julijona Alšèniškè, pol. Julianna Holszańska) und deren Töchtern ${ }^{112}$ zugesagt. Der Großfürst war höchstwahrscheinlich zweimal verheiratet ${ }^{113}$. Aus der ersten Ehe mit Anna, der Tochter des Fürsten von Smolensk, Svjatoslav IV. Ivanovitsch, stammte eine Tochter namens Sophia, die später zur Fürstin von Moskau wurde. Nach Annas Tod im Juli 1418 vermählt sich Witold noch im selben Jahr mit Uljana, vermutlich einer Tochter

Numizmatyczno-Archeologiczne 13, 1930/1931, S. 65-86, korrigierte; Z. P i e c h, Monety, pieczęcie i herby w systemie władzy Jagiellonów, Warszawa 2003, S. 229; vgl. die jüngste Monographie über die Sphragistik des Großfürsten Witold von E. R i m š a, Lietuvos didžiojo kunigaikščio Vytauto antspaudai ir žemių heraldika, Vilnius 2016 (mit einer ausführlichen englischen Zusammenfassung, S. 179-184). Das litauische Wappen ist nicht nur in Wappenbüchern (A. H e y m o w s k i, Herby polskie w brukselskim Armorial Gymnich, recte Lnycenich, Studia Źródłoznawcze 29, 1985, S. 95-124, hier Taf. VII und XV), sondern auch in den Illustrationen zu Eberhart Windeckes Denkwürdigkeiten überliefert, siehe die Handschrift jener Chronik in: Wien, Österreichische Nationalbibliothek, Cod. 13975/1, fol. 138r (Sigismund Korybut zieht nach Böhmen) und Cod. 13975/2, fol. 324r (Tod des Großfürsten).

110 Das heraldische Symbol wurde seit der Mitte des 16. Jahrhunderts als „Pogon““ bezeichnet (der polnische Begriff wurde später in der weissrusischen Sprache als „Pahonia“ übersetzt), was mit „Verfolgung“ übersetzt werden kann.

${ }_{111}$ Dieses von Witold eingeführte Majestätssiegel wurde noch zumindest von einem seiner Nachfolger als Großfürsten von Litauen, gebraucht - entweder Swidrigal (vermutlich, wenn auch nicht quellenmäßig zu belegen) oder Zygmunt Kiejstutowicz. Zu den Siegeln der Großfürsten siehe weiters Z. P i e c h, Monety, pieczęcie, S. 90-101.

112 Dieser Passus kommt allerdings nur in der Melker Abschrift vor: et omnes successores eiusdem regine verissime denominari debeant et quas presentibus in reginas ex certa sciencia creamus et facimus.

113 J. T ę g o w s k i, Małżeństwa Witolda Kiejstutowicza, Rocznik Polskiego Towarzystwa Heraldycznego, seria nowa 2 (13), 1995, S. 177-182. Einige Behauptungen Tęgowskis werden von C. В. По лех о в, Новые документы о Киевской земле XV века, Сфрагістичний щорічник 2, 2012, S. 267, Anm. 44, korrigiert. 
des Ivan Olgimuntovitsch Olschanski (lit. Jonas Algimantaitis Alšėniškis, pol. Iwan Olgimuntowicz Holszański), wobei eine Dispens für diese Ehe bei der römischen Kurie beantragt wurde. Die Geburt des ersehnten männlichen Nachkommen erlebte Witold in dieser Ehe aber nicht ${ }^{114}$. Dies war ein großes Hindernis für seinen Krönungsplan, besonders wenn man Witolds Alter in Betracht zieht: 1430 war er ungefähr 75 Jahre alt. Vermutlich wurde dem Großfürsten das Recht auf die Bestimmung eines Nachfolgers nach seinem eigenen Wunsch gewährt ${ }^{115}$. Dieses Recht hätte aber wiederum einen wichtigen Punkt im Unionsvertrag von Horodlo verletzt. Obgleich es dem Großfürsten nicht gelang, die Krone für Litauen zu erreichen, wurde seine die unbeschränkte Unabhängigkeit erstrebende Politik in den Grundzügen durch seine Nachfolger im Großfürstentum, nämlich Swidrigal und Zygmunt Kiejstutowicz, weiter fortgesetzt, jedoch ohne Erfolg ${ }^{116}$.

Nicht nur der Krönungsurkunde, sondern auch der Krönungszeremonie wurde geringe Beachtung in der Forschung gewidmet, obwohl wir über interessante Quellen zu diesem letztendlich nicht durchgeführten Festakt verfügen. Die Behauptung von Mickūnaitè, dass die ,royal inauguration was intended as a secular ritual, exactly as the professors et Vienna University had claimed"117, ist nicht ganz präzise. In der königlichen Instruktion wird zwar die Rolle der königlichen Gesandten und des Bündnisabschlusses tatsächlich in den Vordergrund gestellt, doch auch die kirchliche Weihe sollte nach einem ordo coronacionis durchgeführt werden, wenn auch dessen Text oder genauere Angaben über den Ablauf des Rituals nicht überliefert sind ${ }^{118}$.

Die Zeremonie sollte nach der königlichen Anweisung jedenfalls in der folgenden Art und Weise verlaufen ${ }^{119}$ : Der Großfürst und seine Gattin sitzen auf einem prunkvollen (wahrscheinlich erhöhten) Thron (sedentibus duce et ducissa in sede solempnitatis) und von den vor ihnen stehenden Gesandten spricht zunächst die Abordnung des Reichs. Nach der Begrüßung im Namen Sigismunds erinnern sie daran, dass die Erhebung zum König schon am Fürstentag in Łuck vereinbart wurde, wobei zwei Hauptpunkte aus der Krönungsurkunde fast wortwörtlich hervorgehoben werden: die Mission des Großfürsten unter den Heidenvölkern (tamquam apostolo

114 J. N i k o d e m, Witold, S. 447-449. Über die Dispens siehe CEXV II, Nr. 91.

115 Darauf könnte der folgende Satz in der Urkunde hindeuten, wonach die übersandten Kronen auch auf das Haupt etwaiger Nachfolger gesetzt werden durften: vos et ipsa conthoralis vestra et successores vestri more regum possitis solempniter perpetuis temporibus coronari.

116 A. L e w i c k i, Powstanie Świdrygiełły.

117 G. M i c kū n a it è, Making a Great Ruler, S. 74.

118 Die Krönungsordnung ist in der königlichen Instruktion (CEXV II, Nr. 183: habeant oratores regii formam scriptam, qualiter reges coronari et inungi debent), sowie in Joannis Dlugossii Annales, lib. XI, S. 287 (processus omnis coronacionis et unccionis Withaudi et consortis sue Iuliane in regem et reginam) erwähnt. Daneben wird in der Melker Abschrift der Krönungsurkunde ausdrücklich betont, dass Witold und seine Gattin nach Gewohnheit anderer christlicher Könige gesalbt werden sollen. In der Abschrift aus Krakau fehlt die Wendung unctione sacratissima; vgl. Melk, Stiftsbibliothek, Sign. 780/1, fol. 46v: duas coronas materiales -- quibus vos et ipsa conthoralis vestra more regum unctione sacratissima possitis solemniter coronari, und CEXV II, Nr. 182: duas coronas materiales - - quibus vos et ipsa conthoralis vestra et successores vestri more regum possitis solempniter perpetuis temporibus coronari. Welcher ordo coronacionis verwendet werden sollte, läßt sich nur vermuten.

119 Kraków, Biblioteka Książąt Czartoryskich, Ms. 233, S. 403-409. Ed.: CEXV II, Nr. 183. 
Christi, qui gentem Lithuanicam et Samagiticam primus convertit) und dessen Unabhängigkeit von jedem Fürsten oder Herrscher (non habebunt - - pro subditis seu vasallis, sed pro regalibus - - liberis, solum contra insultus coadiutoribus). In ihrer Rede verweisen die Gesandten ferner auf die Autorität des Römischen Reichs als einer Weltmonarchie (ex parte et nomine sue maiestatis et sacri Romani imperii, a quo in hac fragilitate humana fundamentaliter dignitas et huiusmodi coronacionis auctoritas tamquam mundi monarchia procedit) und die königliche Vollmacht zum Vollzug der Krönung.

Nach der Einleitungsrede setzen die Reichsgesandten (oratores imperiales), zu deren beiden Seiten die Gesandten aus Ungarn und Böhmen stehen, gemeinsam mit dem Ortsbischof die Kronen aufs Haupt des Großfürsten und dessen Gattin. Nachfolgend wird vom Bischof die kirchliche Salbung durchgeführt ${ }^{120}$. Während der feierlichen Mahlzeit oder zu einer anderen Gelegenheit werden dem neu gekrönten König und der Königin einige Geschenke in Anwesenheit einer großen Schar übergeben, erst die Pferde, dann die Kriegsgeräte, schließlich die wertvollen Tuche und einige Silbergegenstände ${ }^{121}$.

Am Schluss der Krönungsfeier wird dem König von Litauen durch die Gesandten jeweils aus dem Römischen Reich, Ungarn und Böhmen ein Bündnis angeboten. Die Vertreter des Reichs sprechen jetzt vornehmlich im Namen des Deutschen Ordens als eines Reichsvasallen, der sich mit Litauen verbinden will, um gemeinsam gegen die angriffslustigen heidnischen Nachbarvölker zu kämpfen ${ }^{122}$. Ungarn soll ebenfalls

${ }^{120}$ Ebenda, Nr. 183: oratores imperiales, astantibus ambasiatoribus regnorum Hungarie et Bohemie a latere, capitibus amborum coronas imponant, quam eciam ordinarius domini ducis tangere et iuvare potest imponere, et demum idem ordinarius tam ducem quam ducissam inungat. Die kirchliche Weihe sollte höchstwahrscheinlich von Bischof Matthias von Wilna (1422-1453) durchgeführt werden; zu ihm siehe T. G r a ff, Episkopat monarchii jagiellońskiej w dobie soborów powszechnych XV wieku, Kraków 2008, S. 47-50.

${ }^{121}$ CEXV II, Nr. 183: in multitudine populi astante regi et regine presentent munera, primo equos et arma, demum pannos et in ultimo argentaria.

122 Ebenda: ut vestra excellencia huiusmodi auxillium ex parte imperii senciat, adiungit vobis et vestris succesoribus wenerabilem magistrum Cruciferorum de Prussia et Lywonia et totum ordinem Prutenorum omnesque prelatos Lywonie, suos imperii sacri vasallos. Gerade während der Regierung Sigismunds anerkannten die Hochmeister die Oberhoheit des Reiches eher nur mit Vorbehalt, vgl. O. I s r a e 1, Das Verhältnis des Hochmeisters des Deutschen Ordens zum Reich im 15. Jahrhundert, Marburg a. d. Lahn 1952 (als Manuskript gedruckt). Der Hochmeister Paul von Rusdorf verfolgte „den Krönungssturm“ mit Sorgen, weil er den Deutschen Orden in keinen Konflikt verwickeln wollte. Zurückhaltend unterstützte er den Großfürsten, gleichzeitig signalisierte er aber dem polnischen König seine Bereitschaft zum Friedensschluss. Nach Długosz hätte sich der Hochmeister sogar vor dem polnischen König gerechtfertigt (wenn auch vergeblich), weshalb er die Einladung zur Krönungsfeier empfangen hätte (Joannis Dlugossii Annales, lib. XI, S. 292: Magister Prussie Paulus de Rusdorff consurgens ait divisionem regis et ducis sibi et Ordini suo displicere; vocatum quidem se ad sollempnitatem coronacionis venisse, eo tamen animo esse, ut velit operam se daturum pro reconciliacione regis et ducis et quicquid ad eorum amplitutudinem et honorem pertineret. Responsum illi e vestigio per Sbigneum episcopum est verba sua honesta quidem effectibus non congruere; litere enim Romanorum regis per Baptistam portate et intercepte declarant te et Ordinem tuum dissidium inter fratres quesivisse et procurasse). Über die umsichtige Politik des Deutschen Ordens zu dieser Zeit siehe C. A. Lü ckerath, Paul von Rusdorf. Hochmeister des Deutschen Ordens 1422-1441, Bonn 1969, S. 67-76. 
dem Bündnis beitreten, weil es wie Litauen an der Grenze der christlichen Oikumene liegt ${ }^{123}$. Überraschenderweise wird auch Böhmen in dieses Bündnis einbezogen, dessen einzige Bedeutung darin liegt, dass das Königreich die väterliche Erbschaft darstellt und Sigismund dadurch die Kurfürstenwürde besitzt ${ }^{124}$.

Falls Witold dem Bündnisantrag zustimmt, weisen die Gesandten die königliche Vollmacht zum Bündnisabschluss vor. Sonst sollen sie den Großfürsten durch pulchre raciones von der Nützlichkeit des Bündnisses für alle Christen überzeugen. Wenn Witold einen anderen Vorschlag habe, möge er dann eine eigene mit entsprechender Vollmacht ausgestattete Gesandtschaft zum Römischen König abordnen, der bereit sei, einer solcher Einigung zu beitreten ${ }^{125}$.

\section{FAZIT}

Selbst die geplante und letztendlich nicht realisierte Erhebung Litauens zum Königtum und des Großfürsten zum König war für alle Beteiligten nicht das Ziel an sich. Was für Witold die Festigung und Bestätigung eigener Souveränität bedeutete, war umgekehrt für dessen Vetter Władysław Jagiełło und den polnischen Adel eine ernsthafte Gefährdung mit schwerwiegenden Folgen. Die dynastischen Interessen Jagiełłos und Witolds waren aus verständlichen Gründen unversöhnbar. Der polnische König war Oberhaupt nicht nur des Königreichs Polen, sondern auch des Großfürstentums einschließlich mancher russischen Länder und diese einheitliche Herrschaft wollte er seinem legitimen männlichen Nachfolger ungeteilt vermachen. Daneben lag es in den Lebensinteressen des polnischen Adels, dass die Union Polens und Litauens weiterhin bewahrt blieb.

Dagegen verfolgte Sigismund mit dem neu eingerichteten Königtum in Litauen zwei Ziele. Zunächst wollte er die Einmischung des polnischen Königs in die nicht immer reibunglosen Verhandlungen bezüglich der Rückkehr der Hussiten in den Schoß der katholischen Kirche verhindern. Ferner, was für ihn nicht weniger relevant war, wollte er eine Allianz mehrerer Bündnisstaaten (Ordensstaat, Litauen, Ungarn und Böhmen) bilden, die ein Bollwerk gegen die aus dem Süden und Osten drohenden Gefahren darstellen sollte ${ }^{126}$. Um diesen Plan in die Wirklichkeit umzusetzen,

${ }^{123}$ CEXV II, Nr. 183: Sicut enim vestre excellencie dominia se ab accione maris usque ad mare Naurum [sic!] amplitudine longa protendunt, in quibus scutum cristianorum existit, regna quoque et dominia maiestatis regie et corone regni sui Ungarie ....... [Textlücke] vobiscum conterminant et ab eodem ad mare Mediterraneum, in quibus pari modo ipse ianitor et clipeus cristianismi existit. Zum Begriff scutum cristianorum siehe weiter P. S rodecki, Antemurale Christianitatis. Zur Genese der Bollwerksrhetorik im östlichen Mitteleuropa an der Schwelle vom Mittelalter zur Frühen Neuzeit, Husum 2015.

${ }^{124}$ CEXV II, Nr. 183: precipuum et notabile membrum et electoratus potissimus sacri Romanorum existit imperii et vera hereditas domini nostri regis prefati.

${ }^{125}$ Ebenda: persuadeant pulcris racionibus, quod utile sit cristianitati et omnibus nobis, quod ista unio ibidem consumetur. In casu vero, quo domino [duci] magno aliud videretur, quia tunc super illo ambasiatores suos plene fulcitos ad regiam maiestatem transmittat et maiestas sua parata erit huiusmodi unionem feliciter consumare.

${ }^{126}$ Ein Blick auf die Landkarte verdeutlicht, dass die Bündnisstaaten (Böhmen ausgenommen) einen sich von Ostsee zum Schwarzen Meer fast ununterbrochen ziehenden Gürtel bilden. Zwischen Ungarn und Litauen war jedoch das um die Mitte des 14. Jahrhunderts entstandene 
bediente sich Sigismund erprobter symbolischer Handlungen, die als spezifisch mittelalterliche, aber auch allgemein anthropologische zu betrachten sind: die wertvollen Gaben, welche Witold und dessen Gattin tatsächlich erhielten und bei der vergeblich ersehnten Krönungsfeier noch bekommen sollten ${ }^{127}$; die Aufnahme in die Hofgesellschaft durch die Verleihung der Drachenordensinsignien; die Bezeichnung des Großfürsten mit dem Titel Apostel (apostolus Domini) der heidnischen Völker und Verbreiter des christlichen Glaubens; die vorgesehenen Krönungsfeierlichkeiten mit den anwesenden Repräsentanten der von Sigismund beherrschten Länder; und nicht zuletzt die Verleihung des Königstitels aufgrund der Autorität des Heiligen Römischen Reiches, d. h. der Weltmonarchie ${ }^{128}$.

Der „Krönungssturm“, den Sigismund selbst ausgelöst hatte, entwickelte sich nur teilweise nach seinem Wunsch. Jagiełło wurde zwar dadurch von der Sache der Hussiten abgebracht, doch die vorgesehene Koalition wurde nicht gebildet. Dieses zweite Ziel des Römischen Königs wäre wahrscheinlich auch erreicht worden, wenn nur günstigere Umstände es ermöglicht hätten. Deshalb unternahm Sigismund alle denkbaren Maßnahmen. Selbst der Tod des Großfürsten am 27. Oktober 1430 hinderte den König keineswegs daran, diesen Plan weiterzuverfolgen.

Fürstentum Moldau als Keil gesetzt, das damals ein Zankapfel zwischen Polen, Ungarn und dem Türkischen Reich war. Es ist also nicht zufällig, dass Sigismund während der Tagung in Łuck 1429 dem polnischen König die Aufteilung jenes Fürstentums anbot (Joannis Dlugossii Annales, lib. XI, S. 249; weiter siehe I. C z a mań s k a, Mołdawia i Wołoszczyzna wobec Polski, Węgier i Turcji w XIV i XV wieku, Poznań 1996). Über die Verstrickung jenes Fürstentums in die Politik Sigismunds einerseits und der Union Polen-Litauens anderseits siehe jüngst M. Whelan, A. S i m o n, The Moldavian Lady and the Elder Lords of the East, Transylvanian Review 24, 2015, Nr. 3, S. 113-129.

${ }^{127}$ Zur Diskussion über den Gabentausch im Mittelalter und in der Frühneuzeit aus anthropologischer Sicht siehe jüngst G. A 1 t h off, B. S t o 11 b e rg-R i ling e r, Die Sprache der Gaben. $\mathrm{Zu}$ Logik und Semantik des Gabentauschs im vormodernen Europa, Jahrbücher für Geschichte Osteuropas NF 63, 2015, S. 1-22, und M. W in k l e r, Die Macht der Gaben - ein Kommentar, ebenda, S. 99-108.

${ }^{128}$ Als Erwiderung darauf sollte Witold ein verlässlicher Verbündeter des Römischen Königs und Reichs werden. 
QUELLENANHANG: Edition der Krönungsurkunde

[vor 1430 Juli 4]

Überlieferung: Abschrift aus dem 7. Jahrzehnt des 15. Jahrhunderts (Formelbuch des Konrad von Würzburg) in: Melk, Stiftsbibliothek, Sign. 780/1, fol. 45v-46v (pag. 90-92) (M); die vorgenannte Hds. liegt der von F. M. Pelzel um das Jahr 1777 abgefertigten Abschrift aus dem 18. Jahrhundert in: Praha, Národní knihovna České republiky, Oddělení rukopisů a starých tisků (Handschriftenabteilung), Sign. XIX A 1, fol. 86v-88r (P) zugrunde; eine dritte von der Melker Hds. erheblich abweichende Abschrift in: Kraków, Biblioteka Książąt Czartoryskich, Ms. 233, S. 409-412 (K).

Ed.: CEXV II, Nr. 182 (nach $\mathbf{K})$.

Vorbemerkung zur Edition: Als Vorlage für die kritische Edition wurden sowohl Abschrift $\mathbf{M}$ als auch $\mathbf{K}$ benutzt, ohne einer Abschrift eindeutig den Vorrang zu geben. Daher werden Zusätze, die nur in einer der beiden Abschriften überliefert sind, jeweils in der entsprechenden Spalte ausgewiesen (M links, bzw. K rechts). Kritische Textbemerkungen zur lateinischen Sprache folgen dem System des Textapparates bei P. Elbel, Neznámý list krále Zikmunda litomyšlskému biskupu Janovi Železnému ze 4. záŕí 1417. Edice, rozbor a komparace se Zikmundovým listem Čechům téhož data, in: Querite primum regnum Dei. Sborník př́ispěvků k poctě Jany Nechutové, Brno 2006, S. 515-534. Abkürzungen: add. - addidit; om. - omisit; em. - emendavit; sec. - secundum.

In nomine sancte et individue trinitatis feliciter, amen. Sigismundus Dei gracia Romanorum rex semper augustus ac Ungarie, Bohemie, Dalmacie, Croacie ${ }^{1}$ etc. rex ${ }^{2}$ serenissimo principi domino Alexandro Litwanie etc. regi ${ }^{3}$ fratri nostro carissimo salutem et fraterne dileccionis continuum incrementum et concepta nostra desideria in personam vestram ${ }^{4}$ per nos annuente divina clemencia profusa largissime successu longevi temporis in vobis, heredibus et successoribus vestris, feliciter prosperari ${ }^{5}$. Altitudo diviciarum sapiencie et sciencie Dei et occulta iudicia ${ }^{6}$ inscrutabiles $^{7}$ eius vie noscuntur ${ }^{8}$, Deus omnipotens ab origine mundi creacionis et plasmati hominis, quem formavit divinum tantis dotibus ${ }^{9}$ racionis et ingenii ${ }^{10}$ subtilitate armavit, $\mathrm{ut}^{11}$, si preceptis Domini indesinenter ${ }^{12}$ servatis sine labe peccati stare solidus $^{13}$ voluisset, semper viveret ${ }^{14}$, nec ad ${ }^{15}$ serpentis antiqui hostis suasionibus ${ }^{16}$

${ }^{1}$ dei gracia ... etc. Croacie om. $\mathbf{M}, \mathbf{P}$

2 rex om. $\mathbf{M}, \mathbf{P}$

${ }^{3}$ etc. regi : regi etc. $\mathbf{K}$

${ }^{4}$ vestram bis $\mathbf{K}$

${ }^{5}$ prosperari : consperari $\mathbf{K}$

6 et add. $\mathbf{K}$

${ }^{7}$ scrutabiles om. $\mathbf{K}$

${ }^{8}$ Cf. Rom 11:33: O altitudo divitiarum sapientiae, et scientiae Dei: quam incomprehensibilia sunt iudicia eius, et investigabiles viae eius!

${ }^{9}$ dotibus exaravit et em. ad documentis $\mathbf{K}$

10 ingenii : ingenis $\mathbf{P}$

11 armavit ut : ornavit et $\mathbf{K}$

12 indesinenter : indeficienter $\mathbf{K}$

13 solidus : solidius $\mathbf{K}$

14 viveret $\mathrm{om} . \mathbf{K}$

15 ad om. K

16 suasionibus om. K 
mortis ${ }^{17}$ exicium declarasset, sed quia casu flebili ${ }^{18}$ prevaricato Dei mandato per gustum pomi vetiti ${ }^{19}$ incidit mortis sentenciam, a quadam ${ }^{20}$ traduce fortis $^{21}$ in filios, eciam ipsa posteritas facilis est ad lapsum, propter quod malicia hominum excrescente per mundum et populo augmentato ipsi homines ad mala $<\mathbf{K}$ pag. $\mathbf{4 1 0}>$ proclivi in se ipsos crudeli ${ }^{22}$ facinore sevierunt, $<\mathbf{P}$ fol. $\mathbf{8 7} \mathbf{r}>$ ut nedum ${ }^{23}$ quisquis alterius bona violenter diriperet, verum se ipsos pro facili et iniusta ${ }^{24}$ causa mutuo ${ }^{25}$ mortibus trucidarent ${ }^{26}$, necesse fuit, ut ad edomandam ${ }^{27}$ insolenciam faccionum, ad vindictam malorum, laudem vero bonorum principes et reges preficerentur gentibus et preessent, sicque actum est, ut qui $<\mathbf{M}$ fol. $\mathbf{4 6 r}>$ lege naturali et iusto ordine rem publicam celebrius gubernasset, amplioris laudis et glorie titulis premineret ${ }^{28}$.

Sane, si condecet dicere, ymmo racione dictante provida congruit non tacere ad vestre serenitatis laudem ${ }^{29}$ titulis consurgimus gloriosis ${ }^{30}$ et ecce altissimo disponente, cum ad ducalis principatus eminentiam persona vestra post etatis teneris ${ }^{31}$ decursum laudabiliter provolasset, ipsa vestra serenitas tunc in minoribus ${ }^{32}$ constituta iusticiam dilexit, pacem fovit et regimen populi ad ipsorum commodum et profectum sollicitus ${ }^{33}$ gubernavit, nec hiis terrenis et commendandis ${ }^{34}$ contenta virtutibus ad Dei laudem et gloriam ad fidei christiane votivum augmentum ${ }^{35}$ plurimos $^{36}$ gentes barbaras

[nach K] precipue tamen gentem Lithwanicam et Samagiticam, tamquam apostolus Domini sua diligencia primitus

convertit ad fidem et lavacro felicis baptismatis spiritus sancti gracia disponente sacravit, nedum ecclesias metropoliticas et $^{37}$ cathedrales fundavit, instituit et erexit, sed et statum personarum ecclesiasticarum et clericorum ${ }^{38}$ de donis vobis a Deo collatis in victualibus, emolumentis, possessionibus et fructibus sufficienter dotavit,

${ }^{17}$ mortis : mentis $\mathbf{P}$; mortem $\mathbf{K}$

${ }^{18}$ flebili : fallibili $\mathbf{K}$

19 vetiti : fetiti $\mathbf{K}$

${ }^{20}$ quadam : qua $\mathbf{K}$

${ }^{21}$ fortis : sorde $\mathbf{K}$

22 crudeli : crudesi $\mathbf{K}$

${ }^{23}$ nedum : modum $\mathbf{K}$

${ }^{24}$ iniusta : iusta $\mathbf{K}$

25 mutuo : mutuis $\mathbf{K}$

${ }^{26}$ trucidarent : trucidantur $\mathbf{K}$

27 edomandam : domandam $\mathbf{K}$

${ }^{28}$ premineret : preveniret $\mathbf{K}$

29 laudem : laudis $\mathbf{K}$

${ }^{30}$ titulis consurgimus gloriosis : titulos consugimus gloriosos $\mathbf{K}$

31 teneris : tenerioris $\mathbf{P}$; tenoris $\mathbf{M}$

32 minoribus : imminotibus $\mathbf{K}$

${ }^{33}$ sollicitus : sollicicius $\mathbf{K}$

${ }^{34}$ commendandis : commendandum $\mathbf{K}$

35 votivum augmentum : votum augmentatum $\mathbf{K}$

${ }^{36}$ plurimos om. K

37 et $\mathrm{om} . \mathbf{K}$

${ }^{38}$ clericorum : ecclesiarum $\mathbf{K}$ 
unde ipsa sancta mater ecclesia letatur ${ }^{39}$; verum ${ }^{40}$ serenitas vestra adhuc non cessat ad ulteriora procedere et conterminas nationes nedum ${ }^{41}$ instruccione induccione ${ }^{42}$, sed et manu potencie et virtuosis actibus ad fidem catholicam revocare. Quo sit, $\mathrm{ut}^{43}$ et merito digniori titulo succrescatis et induamini ${ }^{44}$ potencia glorie amplioris, ut desiderium vestrum per lata ${ }^{45}<\mathbf{K}$ pag. $411>$ spacia gencium infidelium dilatare et t $^{46}$ fidem ipsam valeatis in Domino robuscius ampliare; et ut vobis aperiamus perlucide $<\mathbf{P}$ fol. 87v $>$ nostre pie voluntatis affectum, concepimus personam vestram dictis meritis exigentibus, ut vos et heredes vestri et successores fervenciores efficiamini ad fidem catholicam ampliandam, ad regalis fastigii gloriam et honorem motu proprio, $n^{n e}{ }^{47}$ vestris, nec alicuius hominis precibus, sed divina gracia nobis, ut tenemus ${ }^{48}$ firmiter, inspirante, optatis titulis insignire.

Idcirco non improvide, nec per errorem ${ }^{49}$, sed animo deliberato sano, principum, comitum, baronum, procerum et fidelium nostrorum accedente consilio, serenitatem vestram, heredes et successores vestros in perpetuos reges Lithwanie ${ }^{50}$, ipsamque terram et ducatum, prout in sua amplitudine continetur in regnum creavimus, insignivimus, elevavimus ${ }^{51}$, transtulimus ${ }^{52}$, ereximus, intitulavimus ${ }^{53}$ et extulimus $^{54}$, creamus, insignimus, elevamus, transferimus ${ }^{55}$, erigimus, intitulamus et attolimus $<\mathbf{M}$ fol. $\mathbf{4 6} \mathbf{v}>$ per presentes sic videlicet, ut ex nunc ${ }^{56}$ in antea serenissimus et verus gloriosus et liber rex ${ }^{57}$ per orbem universum intitulari, scribi, appellari et nominari debeatis et ${ }^{58}$ vos ipsos eciam ${ }^{59}$ tales reges illustrissimos nominare et scribere, renitencia, rebellione seu malivolencia non obstante ${ }^{60}$ quorumcunque ac eciam omni ${ }^{61}$ libertate, privilegio, iure, immunitate ${ }^{62}$, quibus ceteri reges ${ }^{63}$ utuntur et gaudent, similiter utifrui et gaudere

39 sancta mater ecclesia letatur : mater sancta letatur ecclesia $\mathbf{K}$

${ }^{40}$ verum : sed $\mathbf{K}$

${ }^{41}$ nedum : nondum $\mathbf{K}$

42 instructione inductione : instructorum inductorum $\mathbf{P}$; inductionem instructionem $\mathbf{K}$

${ }^{43}$ ut : quatenus $\mathbf{K}$

44 induamini : induenum $\mathbf{K}$

${ }^{45}$ lata : loca $\mathbf{K}$

46 et $:$ in $\mathbf{K}$

${ }^{47}$ nec om. $\mathbf{P}$

48 tenemus om. $\mathbf{K}$

49 non improvide, nec per errorem : non per errorem autem aimprovide $\mathbf{K}$

${ }^{50}$ Lithwanie : Litwanie $\mathbf{M}$

${ }^{51}$ creavimus, insignivimus, elevavimus : creamus, insignimus, elevamus $\mathbf{K}$

${ }^{52}$ transtulimus om. $\mathbf{M}, \mathbf{P}$

53 intitulavimus : intitulamus $\mathbf{K}$

${ }^{54}$ extulimus om. $\mathbf{K}$

${ }^{55}$ transferimus om. $\mathbf{M}, \mathbf{P}$

${ }^{56}$ ut ex nunc: quod ex tunc $\mathbf{K}$

57 serenissmus et ... rex : vestra celsitudo et vestri successores reges Lithwanie serenissimi veri gloriosi et liberi reges $\mathbf{K}$

${ }_{58}$ debeant add. $\mathbf{K}$

59 etiam : et $\mathbf{K}$

${ }^{60}$ obstante : obstantibus $\mathbf{K}$

${ }^{61}$ honore add. $\mathbf{K}$

${ }^{62}$ et dignitate add. $\mathbf{K}$

${ }^{63}$ liberi add. $\mathbf{K}$ 
[nach M] et regnum vestrum cum ter- sic quod ex honore, quem vobis libenter ris, dominiis et possessionibus a barbaris edicimus, nichil libertatis vobis et regno nacionibus captis [ms. captas] in aug- vestro obstruatur, quin ymo sicut actenus mentum fidei christiane dilatare, libere vestra serenitas dux liber extiterat, sic et publice valeatis. imposteri regio decorata decore vos et successores vestri reges liberi nec nobis, nec sacro imperio, nec cuicunque alteri subditi seu vasalli, sed solum ut cristianorum in illis finibus clipeus [contra] gentiles insultus coadiutores [ $\mathrm{ms}$. quoadiutores] persistatis.

Et in signum huiusmodi ${ }^{64}$ magnificencie et exaltacionis gloria robuscius confirmanda, vobis et serenissime principi, domine Juliane ${ }^{65}$ conthorali $<\mathbf{K}$ pag. $412>$ vestre carissime, que similiter et omnes successores eiusdem regine verissime [ms. verissimis] denominari debeant et quas presentibus in reginas ex certa sciencia creamus et facimus, duas coronas materiales auro et geminis preciosissimis ${ }^{66}$ decoratas per oratores $^{67}$ et nunccios nostros solempnes ${ }^{68}$

hic presentes, videlicet A. B. C., pro nobis et sacro imperio, a quo huiusmodi coronacionis auctoritas tamquam a mundi monarchia procedit, plenum mandatum et facultatem ad coronandam vestram celsitudinem et illustrissimam consortem vestram habentes, quam potestatem et facultatem ipsis damus et tribuimus presencium per tenoris vigorem

in favorem specialis dileccionis, quam ad vos plena sinceritate gerimus $\langle\mathbf{P}$ fol. 88r $>$ in visceribus caritatis, transmittimus, quas indubitanter vobis utrisque dedimus gratas ${ }^{69}$ plurimum et acceptas, quibus vos et ipsa conthoralis vestra et successores vestri ${ }^{70}$ unccione sacratissima ${ }^{71}$ possitis solempniter ${ }^{72}$ perpetuis temporibus ${ }^{73}$ coronari, addicientes et dantes v[estre] f[raternitati] arbitrium liberum et plenariam potestatem,

\footnotetext{
${ }^{64}$ huiusmodi: huius $\mathbf{M}, \mathbf{P}$

${ }^{65}$ Juliane : Johanne $\mathbf{M}, \mathbf{P}$; em. sec. $\mathbf{K}$

${ }^{66}$ preciosissimis : preciosis $\mathbf{K}$

${ }^{67}$ per oratores om. $\mathbf{K}$

${ }^{68}$ solempnes : sollemnes $\mathbf{M}, \mathbf{P}$

${ }^{69}$ vobis ... gratas om. et add. acceptas $\mathbf{P}$; dedimus gratas : credimus grates $\mathbf{K}$

70 et successores vestri om. $\mathbf{M}, \mathbf{P}$

71 unctione sacratissima om. $\mathbf{K}$

${ }^{72}$ solempniter : solemniter $\mathbf{M}$; solenniter $\mathbf{P}$; em. sec. $\mathbf{K}$

${ }^{73}$ perpetuis temporibus om. $\mathbf{M}, \mathbf{P}$
} 
quod arma seu insignia v[estra] et regni vestri, que veri predecessores magni duces Lithwanie et vestre serenitatis hucusque gestare soliti estis, retinere vel in quamcumque formam [ms. favorem] aliam vobis placabilem inmutare [ms. invitare] et meliorare possitis, sicut plerique alii reges cristianorum hucusque fecerunt et sicut vobis melius videbitur expedire.

Nulli ergo omnino ${ }^{74}$ hominum liceat hanc nostre creacionis, ereccionis et corone ${ }^{75}$ donacionis, intitulacionis, immunitatis, libertatis et insignicionis paginam infringere vel ei ausu temerario verbo vel facto quomodolibet contraire. Si quis quacunque occasione quesita in contrarium quidquid ${ }^{76}$ attemptare presumpserit, indignacionem omnipotentis Dei et sacri Romani imperii ac

penam centum millium marcarum auri purissimi se noverit incursurum, vobis ${ }^{77}$ et successoribus vestris irremissibiliter persolvendam. Testes etc. ${ }^{78}$

\section{BIBLIOGRAFIA}

$1413 \mathrm{~m}$. Horodlès aktai (dokumentai ir tyrinèjimaj) / Akty horodelskie z 1413 roku (dokumenty i studia), hg. von J. Kiaupienè, L. Korczak, Vilnius-Kraków 2013.

Althoff G., Stollberg-Rilinger B., Die Sprache der Gaben. Zu Logik und Semantik des Gabentauschs im vormodernen Europa, Jahrbücher für Geschichte Osteuropas NF 63, 2015.

Annas G., Hoftag - Gemeiner Tag - Reichstag. Studien zur strukturellen Entwicklung deutscher Reichsversammlungen des späten Mittelalters (1349-1471), Bd. II, Göttingen 2004.

Bardach J., Krewo i Lublin. Z problemów unii polsko-litewskiej, in: Derselbe, Studia z ustroju i prawa Wielkiego Księstwa Litewskiego XIV-XVII w., Warszawa 1970.

Beinhoff G., Die Italiener am Hof Kaiser Sigismunds (1410-1437), Frankfurt a. M. 1995.

Błaszczyk G., Burza koronacyjna. Dramatyczny fragment stosunków polsko-litewskich w XV wieku, Poznań 1998.

Błaszczyk G., Dzieje stosunków polsko-litewskich, t. II, Poznań 2007.

Čapský M., Vévoda Přemek Opavský (1366-1433). Ve službách posledních Lucemburků, Brno-Opava 2005.

Coufal D., Polemika o kalich mezi teologií a politikou 1414-1431. Předpoklady basilejské disputace o prvním z pražských artikulů, Praha 2012.

Czamańska I., Mołdawia i Wołoszczyzna wobec Polski, Węgier i Turcji w XIV i XV wieku, Poznań 1996.

Drabina J., Papiestwo - Polska w latach 1384-1434, Kraków 2003.

Dücker J., Sigismund und der Konflikt um die Königskrönung Witolds von Litauen (1429/30), in: Emperor Sigismund and the Orthodox World, Wien 2010.

Dvořáková D., Čierná královná Barbora Celjská (1392-1451). Životný príbeh uhorskej, rímsko-nemeckej a českej královny, Budmerice-Bratislava 2013.

\footnotetext{
${ }^{74}$ omnino om. M, $\mathbf{P}$

${ }^{75}$ corone : coronationis $\mathbf{K}$

${ }^{76}$ quidquid: quidquam $\mathbf{M}, \mathbf{P}$

77 vobis om. K

78 testes etc. om. $\mathbf{K}$
} 
Elbel P., „Scio, quod vos Moravi estis timidi et michi non fideles“. Moravané ve strukturách dvora Zikmunda Lucemburského, Mediaevalia historica Bohemica 12, 2009.

Erkens F.-R., Über Kanzlei und Kanzler König Sigismunds. Zum Kontinuitätsproblem in der deutschen Königskanzlei unter dem letzten Luxemburger, Archiv für Diplomatik 33, 1987.

Forstreiter E., Die deutsche Reichskanzlei und deren Nebenkanzleien unter Kaiser Sigmunds von Luxemburg, Wien 1924 (Diss. Masch.).

Glassner Ch., Katalog der deutschen Handschriften des 15. und 16. Jahrhunderts des Benediktinerstiftes Melk. Katalog- und Registerband, Wien 2016.

Goll J., König Sigmund und Polen, Mitteilungen des Instituts für Österreichische Geschichtsforschung 15, $1894-16,1895$.

Górska-Gołaska K., Zasadzka rycerstwa wielkopolskiego na drodze margrabskiej pod Turzą Górą w 1430 r., Studia i Materiały do Dziejów Wielkopolski i Pomorza 12, 1976, z. 1 (23).

Graff T., Działalność polityczna Zbigniewa Oleśnickiego i polskiej hierarchii kościelnej w dobie burzy koronacyjnej, Folia Historica Cracoviensia 14, 2008.

Graff T., Episkopat monarchii jagiellońskiej w dobie soborów powszechnych XV wieku, Kraków 2008.

Graus I., Dračí rád Žigmunda Luxemburského a jeho symbolika, Slovenská archivistika 31, 1996.

Graus I., Rád Draka a jeho insignie, Vojenská história 10, 2006.

Gumowski M., Pieczęcie książąt litewskich, Ateneum Wileńskie 7, 1930.

Hauck K., Halsring und Ahnenstab als herrscherliche Würdezeichen, in: Herrschaftszeichen und Staatssymbolik. Beiträge zu ihrer Geschichte vom dritten bis zum sechszehnten Jahrhundert von Percy Ernst Schramm mit Beiträgen verschiedener Verfasser, t. I, Stuttgart 1954 (Schriften MGH 13/1).

Heymowski A., Herby polskie w brukselskim Armorial Gymnich, recte Lnycenich, Studia Źródłoznawcze 29, 1985.

Hirsch H., Das Recht der Königserhebung durch Kaiser und Papst im hohen Mittelalter, in: Festschrift Ernst Heymann, Bd. I, Weimar 1940.

Hoensch J. K., Kaiser Sigismund. Herrscher an der Schwelle zur Neuzeit 1368-1437, Darmstadt 1997

Hoensch J. K., König/Kaiser Sigismund, der Deutsche Orden und Polen-Litauen. Stationen einer problembeladenen Beziehung, Zeitschrift für Ostmitteleuropa-Forschung 46, 1997.

Israel O., Das Verhältnis des Hochmeisters des Deutschen Ordens zum Reich im 15. Jahrhundert, Marburg a. d. Lahn 1952 (als Manuskript gedruckt).

Jefferson J., The Holy Wars of King Wladislas and Sultan Murad. The Ottoman-Christian Conflict from 1438-1444, Leiden-Boston 2013.

Joachim-Heinig P., Reichsstädte, freie Städte und Königtum 1389-1450. Ein Beitrag zur deutschen Verfassungsgeschichte, Wiesbaden 1983.

Kaar A., Neue Mittel der Kriegsführung? König/Kaiser Sigismund und das Handelsverbot gegen die Hussiten in Böhmen, in: Heilige, Helden, Wüteriche. Herrschaftsstile der Luxemburger (1308-1437), Köln-Weimar-Wien 2017.

Kochanowski J. K., Witold wielki książę litewski. Studium historyczne, Lwów 1900.

Koczerska M., Zbigniew Oleśnicki i kościół krakowski w czasach jego pontyfikatu (14231455), Warszawa 2004.

Kosman M., Małdrzyk Mikołaj, in: Polski słownik biograficzny, t. XIX (1974).

Lewicki A., Powstanie Świdrygiełły. Ustęp z dziejów unii Litwy z Koroną, Kraków 1892.

Lővei P., Hoforden im Mittelalter, unter besonderer Berücksichtigung des Drachenordens, in: Sigismundus Rex et Imperator. Kunst und Kultur zur Zeit Sigismunds von Luxemburg (1387-1437). Ausstellungskatalog, Mainz 2006.

Lückerath C. A., Paul von Rusdorf. Hochmeister des Deutschen Ordens 1422-1441, Bonn 1969.

Łowmiański H., Witold wielki książę litewski, Lituano-Slavica Posnaniensia 7, 1997.

Maleczyńska E., Społeczeństwo polskie pierwszej połowy XV wieku wobec zagadnień zachodnich. Studia nad dynastyczną polityką Jagiellonów, Wrocław 1947. 
Mathies Ch., Kurfürstenbund und Königtum in der Zeit der Hussitenkriege. Die kurfürstliche Reichspolitik gegen Sigmund im Kraftzentrum Mittelrhein, Mainz 1978.

Mickūnaitė G., Making a Great Ruler: Grand Duke Vytautas of Lithuania, Budapest - New York 2006.

Mierau H. J., Kaiser und Papst im Mittelalter, Köln-Weimar-Wien 2010.

Nalewajek A., Dokument w Rocznikach Jana Długosza, Lublin 2006.

Nikodem J., Dlaczego jesienią 1430 r. Witold zrezygnował z planów koronacyjnych?, Lituano-Slavica Posnaniensia 14, 2012.

Nikodem J., Polska i Litwa wobec husyckich Czech w latach 1420-1433. Studium o polityce dynastycznej Władysława Jagiełły i Witolda Kiejstutowicza, Oświęcim ${ }^{2} 2015$.

Nikodem J., Spory o koronację wielkiego księcia Litwy Witolda w latach 1429-1430, cz. 1: „Burza koronacyjna” w relacji Jana Długosza, Lituano-Slavica Posnaniensia 6, 1994.

Nikodem J., Spory o koronację wielkiego księcia Litwy Witolda w latach 1429-1430, Tl. 2: Próba rekonstrukcji wydarzeń, Lituano-Slavica Posnaniensia 7, 1997.

Nikodem J., Witold wielki książę litewski (1354 lub 1355 - 27 października 1430), Kraków 2013.

Nikodem J., Zbigniew Oleśnicki w historiografii polskiej, Kraków 2001.

Nowak Z. H., Kaiser Siegmund und die polnische Monarchie, Zeitschrift für historische Forschung 15, 1988.

Ożóg K., Uczeni w monarchii Jadwigi Andegaweńskiej i Władysława Jagiełły (1384-1434), Kraków 2004.

Petrauskas R., Korona Witolda: niedoszła koronacja i jej późniejsza legenda historyczna, in: Tradycja - metody przekazywania i formy upamiętnienia w państwie polsko-litewskim, XV - pierwsza połowa XIX wieku, Warszawa 2011.

Pfitzner J., Groszfürst Witold von Litauen als Staatsmann, Brünn-Prag-Leipzig-Wien 1930.

Piech Z., Monety, pieczęcie i herby w systemie władzy Jagiellonów, Warszawa 2003.

Popović M. S., The Order of the Dragon and the Serbian Despot Stefan Lazarević, in: Emperor Sigismund and the Orthodox World, Wien 2010.

Prochaska A., Ostatnie lata Witolda. Studium z dziejów intrygi dyplomatycznej, Warszawa 1882.

Rimša E., Lietuvos didžiojo kunigaikščio Vytauto antspaudai ir žemių heraldika, Vilnius 2016.

Rozbiór krytyczny Annalium Poloniae Jana Długosza z lat 1385-1444, hg. von J. Dąbrowski, t. I, Wrocław 1961.

Scholz M., Günther, Graf von Schwarzburg (1382-1445), in: Die Bischöfe des Heiligen Römischen Reiches 1198-1448. Ein biographisches Lexikon, Berlin 2001.

Schramm P. E., Herrschaftszeichen: gestiftet, verschenkt, verkauft, verpfändet. Belege aus dem Mittelalter, Nachrichten der Akademie der Wissenschaften in Göttingen, Philosophisch-historische Klasse 5, 1957.

Schwertl G., Ernst, Herzog von Bayern-München (1373-1438), in: Lexikon des Mittelalters, Bd. III (1986).

Semkowicz W., Sfragistyka Witołda, Wiadomości Numizmatyczno-Archeologiczne 13, 1930/1931.

Srodecki P., Antemurale Christianitatis. Zur Genese der Bollwerksrhetorik im östlichen Mitteleuropa an der Schwelle vom Mittelalter zur Frühen Neuzeit, Husum 2015.

Szafrański F., Ludwik II brzesko-legnicki, feudał Śląski z doby późnego średniowiecza, Wrocław 1972.

Szybkowski S., Polish Staff as a Social Group in the Chancery of Grand Duke Witold, Quaestiones Medii Aevi Novae 3, 1998.

Szymczakowa A., „Nobiles Siradienses”. Rody Porajów, Pomianów, Gryfów, Kopaczów i Pobogów, Warszawa 2011.

Tęgowski J., Małżeństwa Witolda Kiejstutowicza, Rocznik Polskiego Towarzystwa Heraldycznego, seria nowa 2 (13), 1995. 
Unia w Horodle na tle stosunków polsko-litewskich. Od Krewa do Zaręczenia Wzajemnego Obojga Narodów, Warszawa 2015.

Vytautas Didysis ir Lietuva, Vilnius 1996.

Vytautas Didysis, hg. von P. Sležas, Kaunas 1930, Vilnius ${ }^{2} 1988$.

Wefers S., Das politische System Kaiser Sigmunds, Stuttgart 1989.

Whelan M., Simon A., The Moldavian Lady and the Elder Lords of the East, Transylvanian Review 24, 2015.

Winkler M., Die Macht der Gaben - ein Kommentar, Jahrbücher für Geschichte Osteuropas NF 63, 2015.

Zachorowski S., Consilia w sprawie koronacji Witolda (1429-1430), in: Derselbe, Studia z historii prawa kościelnego i polskiego, Kraków 1917.

Zawitkowska W., Walka polityczno-prawna o następstwo tronu po Władysławie Jagielle w latach 1424-1434, Rzeszów 2015.

Zbigniew Oleśnicki. Książę kościoła i mąż stanu, hg. von F. Kiryk, Z. Noga, Kraków 2006.

Барбашев А., Витовтъ и его политика до Грюнвальденской битвы (1410 г.)., Санкт Петербургъ 1885 .

Барбашев А., Витовтъ. Последния двадцать летъ княжения 1410-1430, Санкт Петербург 1891.

Полехов С. В., Известие хроники Германа Корнера о Вилькомирской битве и его исторический контекст, in: Pabaisko mūšis ir jo epocha, Vilnius 2017.

Полехов С. В., Новые документы о Киевской земле XV века, Сфрагістичний щорічник 2, 2012.

Полехов С. В., Наследники Витовта. Династическая война в Великом княжестве Литовском в 30-е годы XV века, Москва 2015.

\section{„Burza koronacyjna”. Król Zygmunt Luksemburski, wielki książę litewski Witold i nieudana próba ich sojuszu}

Streszczenie

„Burza koronacyjna” nie jest w historiografi (szczególnie polskiej oraz litewskiej) z oczywistych powodów tematem nieznanym. Historycy od czasów Antoniego Prochaski spierają się o znaczenie kryzysu dynastycznego pomiędzy Władysławem Jagiełłą a Witoldem w latach 1429-1430 oraz o jego międzynarodowy wymiar (unia polsko-litewska, polityka Zygmunta Luksemburskiego oraz sprawa husycka). Dostępne źródła (Jan Długosz, korespondencja polityczna), które same w sobie obarczone są wielką dozą subiektywnych interpretacji, pozwalają wprawdzie ustalić przebieg dramatycznych wydarzeń na poziomie faktograficznym i chronologicznym, ale nie zawsze można wyciągać jednoznaczne wnioski co do ich znaczenia. Badacze zwracają w dodatku mniej uwagi na niektóre źródła oraz sprawy związane bezpośrednio z planowaną koronacją Witolda i podniesienia Litwy do rangi królestwa. Chodzi przede wszystkim o dokument koronacyjny dla Witolda, instrukcje dla wysłanników króla rzymskiego, skład delegacji oraz przewidziany przebieg ceremonii koronacyjnej, która nie doszła do skutku. Dokument koronacyjny, którego krytyczna edycja znajduje się w aneksie do artykułu, istnieje dziś w dwóch wersjach (dotychczas była znana tylko dłuższa wersja - kopia w Bibliotece Czartoryskich w Krakowie z XV w.). Podkreślone w dokumencie zasługi Witolda dla chrystianizacji Europy Wschodniej oraz jego niezależność (liber $d u x$ ) od króla rzymskiego i jakiegokolwiek innego władcy posłużyły jako argument za podniesieniem księcia litewskiego do godności królewskiej oraz udzielenia przywileju „ulepszenia” herbu własnego oraz litewskiego. Instrukcje dla delegacji króla rzymskiego zawierają natomiast zwięzły opis uroczystości koronacyjnej oraz projekt sojuszu politycznego. Identyfikacja wysłanników królewskich, dostojników duchownych 
i świeckich pochodzących z Niemiec, Węgier i Czech, świadczy o wysokiej randze owego sojuszu w politycznych planach Zygmunta Luksemburskiego. Te raczej pomijane dotąd źródła i fakty wskazują, że Zygmunt Luksemburski z planowaną koronacją księcia Witolda łączył nadzieje nie tylko na utrudnienie Władysławowi Jagielle zajmowania się sprawą husycką, lecz również na sojusz polityczny z Litwą. O zdecydowanym podejściu Zygmunta do planu owego sojuszu może świadczyć fakt, że nawet po śmierci księcia Witolda próbowano go nadal (choć nieskutecznie) realizować.

\title{
„The coronation storm". King Sigismund of Luxembourg, Grand Duke Vytautas of Lithuania and their unsuccessful alliance attempt
}

\author{
Summary
}

"The coronation storm" is, for obvious reasons, not a new topic in historiography (especially Polish and Lithuanian). From the times of Antoni Prochaska, historians have been disputing the meaning of the dynastic crisis between Władysław Jagiełło and Vytautas during the years 1429-1430 and its international dimension (Polish-Lithuanian Union, Sigismund of Luxembourg's politics, and the Hussite controversy). The available sources (Jan Długosz, political correspondence), which in themselves carry great amount of subjective interpretations, allow to establish the course of dramatic events at the level of factography and chronology, but it is not always possible to draw certain conclusions concerning their meaning. Moreover, researchers pay less attention to some sources and matters directly connected with the planned coronation of Vytautas and raising Lithuania to the rank of kingdom. The most important of these is the coronation document issued to Vytautas, instructions for the envoys of the Roman King, the members of the delegation and the planned course of the ceremony, which eventually did not take place. The coronation document, the critical edition of which is appended to this paper, exists in two versions (until now only the longer version has been known, a copy from the $15^{\text {th }}$ century in the Czartoryski Library in Cracow). The merits of Vytautas for the christianisation of Eastern Europe and his independence (liber $d u x$ ) of the Roman King or any other ruler, which are stressed in the document, served as arguments for raising the Duke of Lithuania to royal dignity and granting him the privilege to "augment" his own and Lithuanian coats-of-arms. The instructions for the legation of the Roman King contain a brief description of the coronation ceremony and a project of a political alliance. The identification of the royal envoys, spiritual and secular dignitaries from Germany, Hungary and Bohemia, testifies to the high rank of that alliance in the political plans of Sigismund of Luxembourg. All these, so far mostly ignored, sources and facts indicate that Sigismund of Luxembourg not only intended to make it difficult for Władysław Jagiełło to deal with the Hussite problem, but also hoped for a political alliance with Lithuania. The importance of that plan for Sigismund may be inferred from the fact that even after Vytautas's death, he continued his (unsuccessful) attempts to realise it. 